\title{
9. RHAETIAN STRATA, WOMBAT PLATEAU: ANALYSIS OF FOSSIL COMMUNITIES AS A KEY TO PALEOENVIRONMENTAL CHANGE ${ }^{1}$
}

\author{
Massimo Sarti, ${ }^{2}$ Antonio Russo, ${ }^{3}$ and Francesca R. Bosellini ${ }^{3}$
}

\begin{abstract}
Rhaetian fossil reef was penetrated on the Wombat Plateau (northern Exmouth Plateau, northwest Australia). A study of fossil populations and associated sediment types showed a vertical transition from a sponge-dominated to a coral-dominated community, with associated hydrozoans-tabulozoans. The first colonization of the mobile ground was undertaken by sponges, whereas the coral community assemblage constituted the main core of a pinnacle reef complex, dominated by Retiophyllia in the lower part and by Astreomorpha associations upward. This change in fossil communities reflected shallowing of the environment of deposition. The density of frame-building organisms at Site 764 , the fossil community organization, and the geometry and spatial arrangement of the organic buildups, as reconstructed by the seismic-reflection profiles, are all instrumental in defining the Rhaetian pinnacle assemblage offshore the Exmouth Plateau as a low-energy, bank-margin "reef complex."
\end{abstract}

\section{INTRODUCTION}

An account of sediment types and fossil communities of the Upper Triassic (Rhaetian) strata on the Wombat Plateau is presented in this paper. The Wombat Plateau is an isolated block of continental crust ornamenting the north-facing edge of the Exmouth Plateau, off the Northwest Shelf of Australia (Fig. 1). The regional geologic and structural setting of the Exmouth Plateau area and surrounding basins is discussed in Falvey and Veevers (1974), Willcox and Exon (1976), von Rad and Exon (1982), Exon and Wilcox (1980), and von Stackelberg et al. (1980), among others.

During the Late Triassic, siliciclastic coastal deposition occurred on the Wombat Plateau, but in the Rhaetian (the last of the Triassic stages) deposition of shallow-water carbonates and reef buildup prevailed, until development of a major ?Late Triassic-Jurassic submarine hiatus (Sarti and Kälin, this volume). As shown by high-resolution seismic-reflection profiles (Williamson et al., 1989), this reefal series at the seaward (northern) side of the Wombat Plateau (Site 764), consisted of pinnacle-shaped buildups (Fig. 2) with a rather narrow base, expanding upward, and with an apron of downlapping clastic wedges of reef-derived detritus enveloping the seismically transparent reef core. Williamson et al. (1989) showed that the pinnacles are numerous between Sites 761 and 764 and rarely coalesce, remaining as isolated columns within the peri-reefal, mud-dominated facies. The aim of this study is to provide a description of the sediment types and biogenic constituents of these buildups.

Late Triassic reef communities are known in some detail only from the Alpine area (Flügel, 1982; Stanton and Flügel, 1987, 1989) and from western North America (Stanley and Whalen, 1989) (Fig. 3), even though they have been reported from numerous other localities in the so-called Tethyan district (see overview in Flügel, 1982, and references therein). As far as systematics and paleoecology are concerned, very few Late Triassic reefs have been examined in detail and several problems remain. No agreement, for example, exists on the

\footnotetext{
1 von Rad, U., Haq, B. U., et al., 1992. Proc. ODP, Sci. Results, 122: College Station, TX (Ocean Drilling Program).

2 Dipartimento di Scienze della Terra, Università della Calabria, Arcavacata, Cosenza, Italy.

3 Istituto di Paleontologia, Università di Modena, Modena, Italy.
}

systematics of Triassic corals, although radical changes in the taxonomic interpretation of other groups (stromatoporoids, "Tabulozoa,"' spongiomorphids, etc.) are frequently proposed. Besides the preceding unsolved problems, difficulties also have arisen from studying cored material with a minimal number of specimens, poor preservation, and commonly unknown spatial relationships for the biota.

In spite of that, we believe that this study can contribute to the knowledge of the Triassic Tethyan reef ecosystems, both from a paleoecological and a paleogeographic standpoint. Our study of fossil communities and sediment types has attempted to reconstruct paleoenvironmental changes, physiographic characteristics of the depositional setting, and the paleoceanographic regimes established at the seaward side of a rift zone off northwest Australia at the end of the Triassic. Moreover, the Triassic carbonates of the Wombat Plateau, situated at the far eastern end of the Mesozoic ocean of Tethys, might represent a linkage with other coeval Triassic successions of the Asian Tethys, Panthalassa (Tollmann and Kristan-Tollmann, 1985), and western North America (Montanaro-Gallitelli et al., 1979; Stanley, 1988; Stanley and Whalen, 1989).

\section{GEOLOGIC SETTING AND STRATIGRAPHIC OVERVIEW FROM DRILLING RESULTS}

A prism of Upper Triassic rocks forms the sedimentary cover of the Wombat Plateau. These lie unconformably over a faulted and tilted pre-Carnian substrate, seen in the seismic record, and are themselves tilted to the north, wedging out basinward. The Wombat horst is gently tilted to the north, and is separated from the Exmouth Plateau "mainland" by the Montebello submarine canyon, an erosionally modified half-graben bounded to the north by southdipping normal faults. The internal geometry of the Triassic rock packages suggests syndepositional deformation and tilting, which probably took place during the formation of the Montebello graben.

A transect of four holes was drilled during Ocean Drilling Program (ODP) Leg 122 through the Wombat Plateau, on the southern side of the high (Sites 759 and 760), at its center (Site 761 ), where there was supposed to be a complete Mesozoic section, and at the northern edge (Site 764), facing the escarpment sloping off into the abyssal plain of Argo (Figs. 1 and 4). 


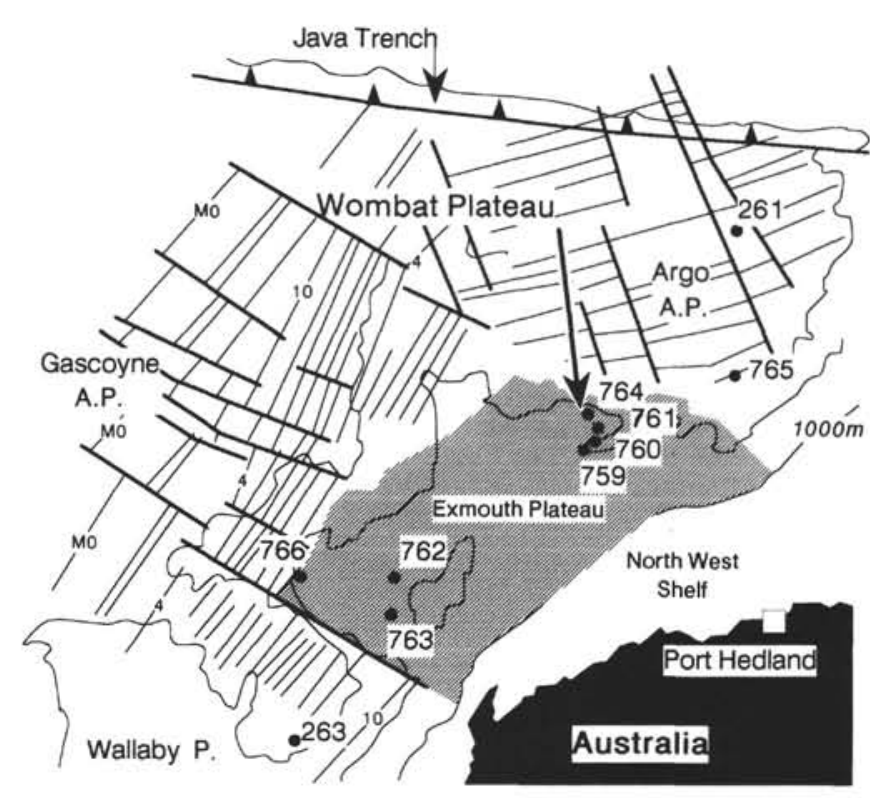

Figure 1. Physiographic-structural map of the northeast Indian Ocean and general location map of the Exmouth Plateau and Argo Abyssal Plain, off the Northwest Shelf of Australia. Thick and thin lines represent transform faults and the magnetic anomaly pattern, respectively. The location of Deep Sea Drilling Project and ODP Leg 122 sites is shown.

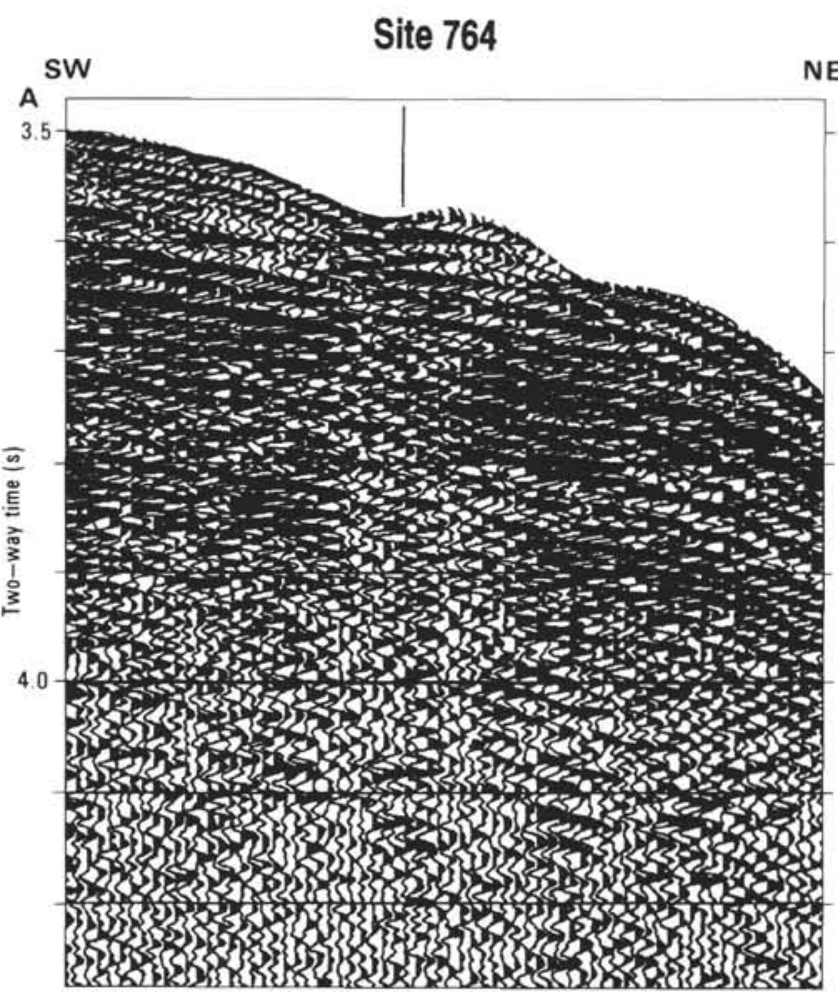

Figure 2. High-resolution seismic profile across Site 764, showing a seismically transparent zone interpreted as a reef-core facies surrounded by slightly reflective units that possibly represent reef-margin clastic wedges (after Williamson et al., 1989).

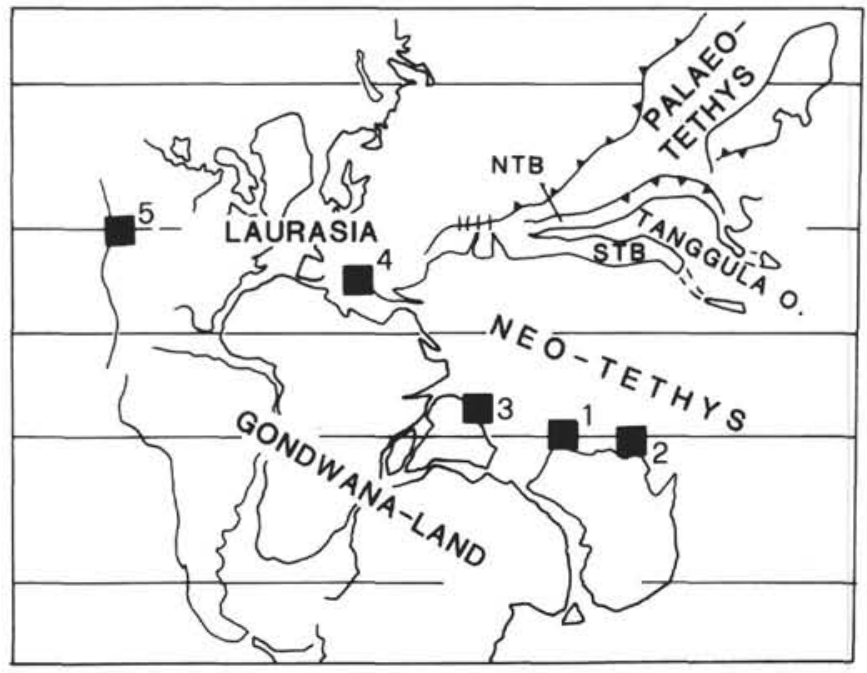

Figure 3. Latest Triassic (Rhaetian) paleogeographic reconstruction of the Mesozoic Tethys (Neo-Tethys), showing the geographic distribution of Rhaetian reefs. Major fossil localities cited in the text are shown: 1 = Exmouth Plateau, 2 = Timor, 3 = Tethys Himalaya, $4=$ Northern Calcareous Alps, and $5=$ western North America. NTB $=$ North Tibet, STB $=$ South Tibet (simplified after Sengör, 1985).

At the two southern sites, a $>400$-m-thick sequence of Carnian and Norian dark-colored claystone, carbonaceous silty claystone, and limestone of a coastal and delta plain environment was encountered, offset by some normal faulting at the edge of the escarpment. The seismic record shows these strata to be northward-dipping and truncated beneath a drape of pelagic sediments (Fig. 4). Northward, these strata are (?)conformably overlain by a Rhaetian shallowwater carbonate package consisting of shelf and coral reefcore facies at Sites 761 and 764 , respectively. At the northern edge of the plateau (Site 764), a thin unit of Rhaetian ferruginous crinoidal calcarenite terminates the shallow-water carbonate unit.

At Sites 759 and 760 , the Triassic strata are draped by undated (?Late Triassic-Jurassic) yellowish and brown ferruginous sandstone, mixed with Cretaceous nannofossils, claystone, and a thick manganese pavement on the southern, more eroded reaches of the high (Site 760). This submarine condensed layer, with a concentration of manganese oxides and belemnite rostra, is overlain by Cretaceous and NeogeneHolocene carbonate chalk and ooze.

The following is an account of sediment types, biota, and diagenetic history of the Rhaetian strata of the Wombat Plateau, with emphasis on the reef-building communities, which provide us with a guide to paleoenvironment change, paleolatitude, and climate control of deposition.

\section{RHAETIAN SEQUENCE AT SITES 761 AND 764}

Site 761 was located on the central Wombat Plateau where the seismic record suggested there was a complete Triassic section. Site 764 was located at the northeastern edge of the Wombat plateau, in an attempt to sample the youngest preunconformity strata. At these locations, a 160 - to 240 -m-thick sequence of Rhaetian carbonates, largely shallow-water in origin, and shale was drilled (Figs. 5 and 6). At Site 761 these strata (?) conformably overlie Norian deltaic mudstones with terrestrial palynomorphs. 

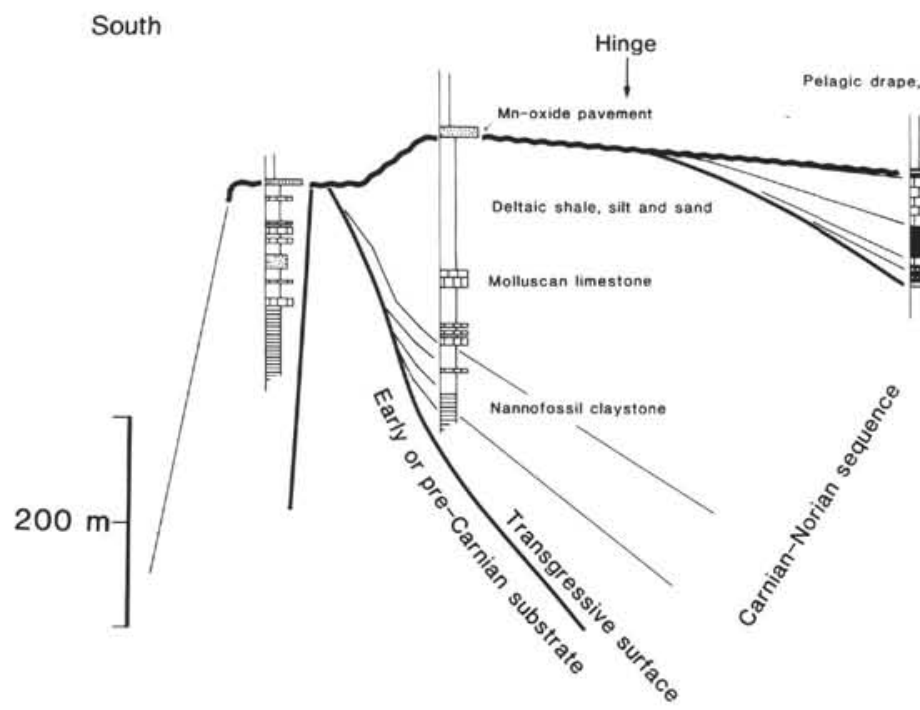

North

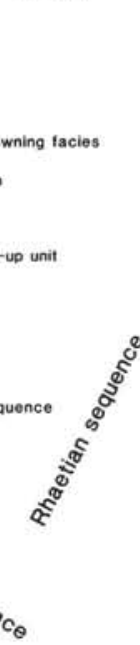

Figure 4. Generalized stratigraphic and structural setting of the Wombat Plateau, showing major Upper Triassic stratigraphic sequences and sequence-bounding unconformities. A simplified lithologic column is shown for each site at its approximate location on the plateau. The wedge-shaped sequence at Sites 761 and 764, resting on Norian deltaic shales, silts, and sands, is a carbonate bank unit including coral and sponge buildups along its north-facing side. Column width represents lithologic type: narrow, pelagic carbonate; medium, coastal to nonmarine shale (plus silt and sand); horizontally ruled, shelf to open marine; wide, calcareous shale and marl; bricks, shallow-water limestone.

\section{Sediment Types and Facies Variations}

The five intervals that make up the Rhaetian series are correlatable among the sites (Fig. 4) and have distinctive lithologic characteristics: (1) a lower interval of thick redeposited beds, rich in crinoidal debris, grading upward into crinoidal carbonaceous shale; (2) a red-colored dolomitic, "rubbly," and nodular horizon, rich in biogenic components; (3) a unit of interbedded biogenic limestone and shale; (4) a package of shallow-water fossiliferous limestone; and (5) rhythmic shale and clayey limestone. A description of the sediment characteristics and microfacies types for each of these units follows.

\section{Interval 1}

Crinoidal unit with redeposited beds (Sections 122-761C$30 R-1,60 \mathrm{~cm}$, through cores $122-761 C-32 R$ and 122-764B$3 I R)$. The lower interval is a 30 -m-thick bioclastic limestone, quartzose sandstone, and shale. Above the unconformity are several graded units, 1 to $1.5 \mathrm{~m}$ thick, consisting of fine- to medium-grained fossiliferous and bioclastic packstone, with abundant crinoidal debris, thin-shelled bivalves, large fragments of mollusk and brachiopod shells and corals, and oncoids. Calcareous sponge spicules, lagenid foraminifers (Lenticulina), and rare Spirillina are characteristic biotic components. Microscopically, samples from the lower 10-20 $\mathrm{cm}$ of each of the graded layers consist of well-sorted, very coarse- to granule-sized crinoidal calcarenites (grainstone) and may contain scattered outsized pieces of mollusk shells, solitary corals (up to $3-4 \mathrm{~cm}$ ), and intraclasts of a crinoidalskeletal calcarenite (1-6 cm across). Isopachous cement of a dogtooth type and clear blocky calcite fill the intergranular space and, rarely, fossil (mollusk) molds.

The lowermost graded bed in this unit, just above the Norian substrate, contains an abundant terrigenous fraction $(15 \%-20 \%)$, with traces of detrital glauconite mixed with a dominantly skeletal and crinoidal component. Most of the quartz and feldspar grains have a well-developed oolitic cortex, suggesting residence of the terrigenous material on shore, before redeposition.

Upward, this unit becomes dominantly shaley, with fewer calcarenite beds $(10-15 \mathrm{~cm})$, consistently rich in crinoid debris. The dominant sediment type is a biomicrite (wackestone) and packstone containing variable proportions of the allochems mentioned previously (especially brachiopods and crinoid ossicles) and numerous Lenticulina foraminifers, thinshelled bivalves, calcareous sponge spicules, brachiopod debris, and small oncoids (400-600 $\mu \mathrm{m})$.

At Site 764 , only the upper $9.6 \mathrm{~m}$ of a crinoid-debrisbearing, gray clayey unit was drilled, which is lithologically correlated with the Norian substrate at Site 761 (the interval of Sections 122-761C-32R-CC, $20 \mathrm{~cm}$, through 122-761C-33R-2, $100 \mathrm{~cm}$ ). These shales or calcareous shales contain quartz debris in trace amounts $(<1 \%)$ and the uppermost sediments are iron stained and slightly to pervasively dolomitized.

\section{Interval 2}

Red-colored, biogenically colonized ground (Section 122$761 C-30 R-1,0-60 \mathrm{~cm}$, and Cores 122-764B-27R through 122$764 B-30 R$ ). A red-colored sponge boundstone overlies the dark gray unit bearing crinoidal and quartz debris with a fairly sharp contact. This distinctive interval is less than $10 \mathrm{~m}$ thick at Site 761, of which only $60 \mathrm{~cm}$ was recovered, and is more than $40 \mathrm{~m}$ thick at Site 764 . Visually, it consists of a very coarse biogenic rubble (floatstone and rudstone) (Fig. 7A), and locally it is a low-relief, organic buildup or a biogenically colonized ground formed by an in-situ growth of a diversified community of building organisms (sphinctozoans, inozoans, and tabulozoans) (Fig. 7B). Microscopically, branched erect sponge bodies are seen bound by a fine-grained fossiliferous and skeletal dolomite (wackestone), with substantial amounts of iron-oxide stain. The sediment color varies from dark flesh pink to dark brick red. Very finely divided iron-oxide minerals are dispersed in the sediment in various amounts. Iron-oxide 


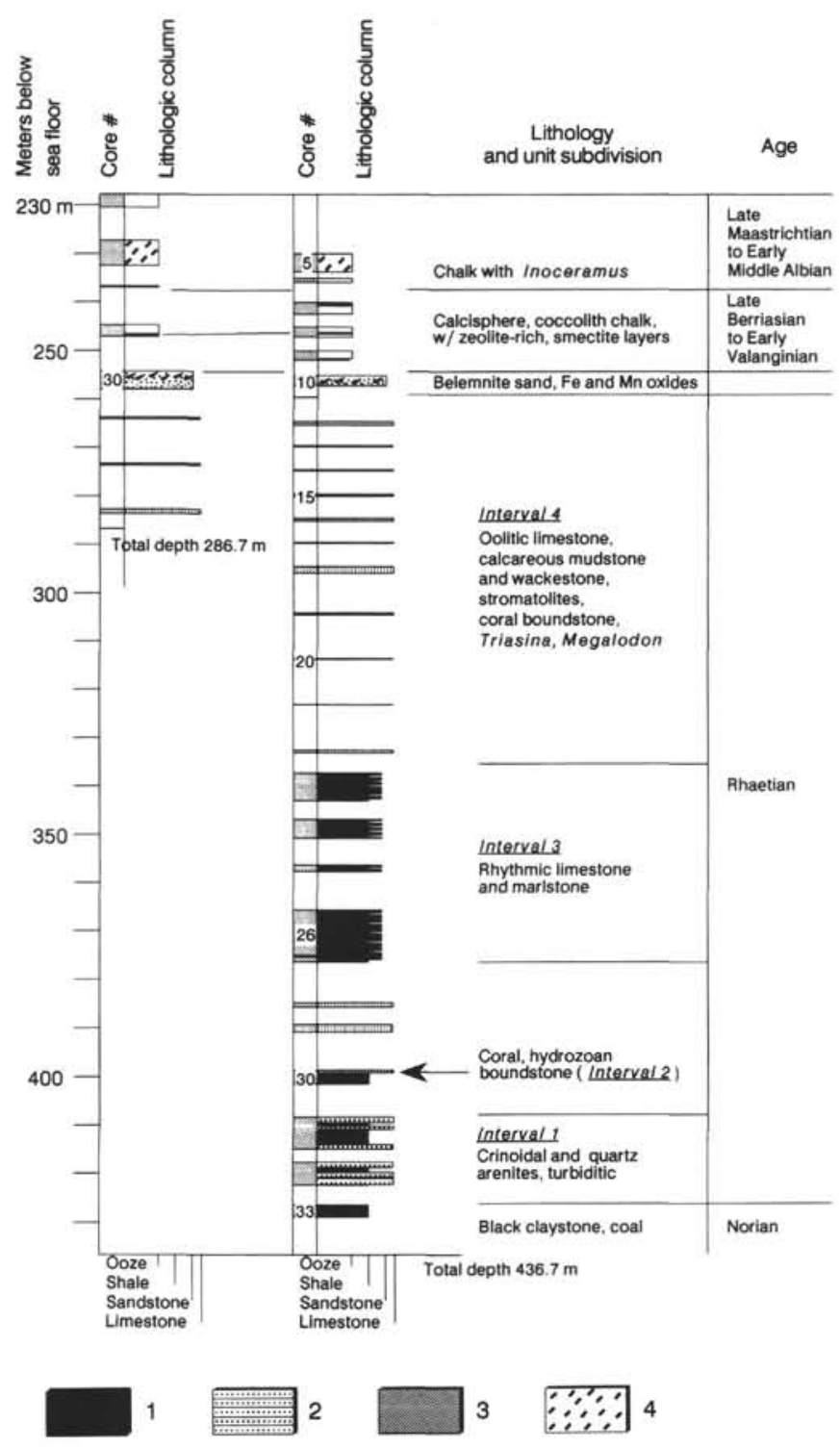

Figure 5. Lithologic column, Site 761. Major lithologic types and units are referred to in the text.

stringers, blebs, micronodules, and concentrations along microstylolite seams also occur (Fig. 7A). Brachiopod, mollusk, and echinoderm debris (both echinoid and crinoid), whole thin-shelled bivalves, Solenopora algal fragments, a few bryozoans, and calcareous sponge spicules are common allochemical components in the red, fine-grained dolomite. Encrusting foraminifer colonies are seen to colonize a sponge body in Sample 122-764B-27R-1, 95-99 cm (see also Pl. 2, Fig. 3 ). Irregularly shaped to globose dissolution cavities of a centimeter scale are present within the matrix. These are primary voids within the sponge framework or, more commonly, fossil (Megalodon) biomolds. A geopetal sediment fill may be present, but more commonly these voids are lined by a thin fringe of acicular or dogtooth marine cement and blocky spar fill (Sarti and Kälin, this volume). Some of the thick, void-filling calcite predates the ferruginous dolomitic fill.

This biogenic interval is punctuated by a few intraclast breccia layers, as much as several centimeters thick, formed by angular elements of micritic limestone, $1-4 \mathrm{~cm}$ across. The micrite forming the intraclasts has the same fossil components

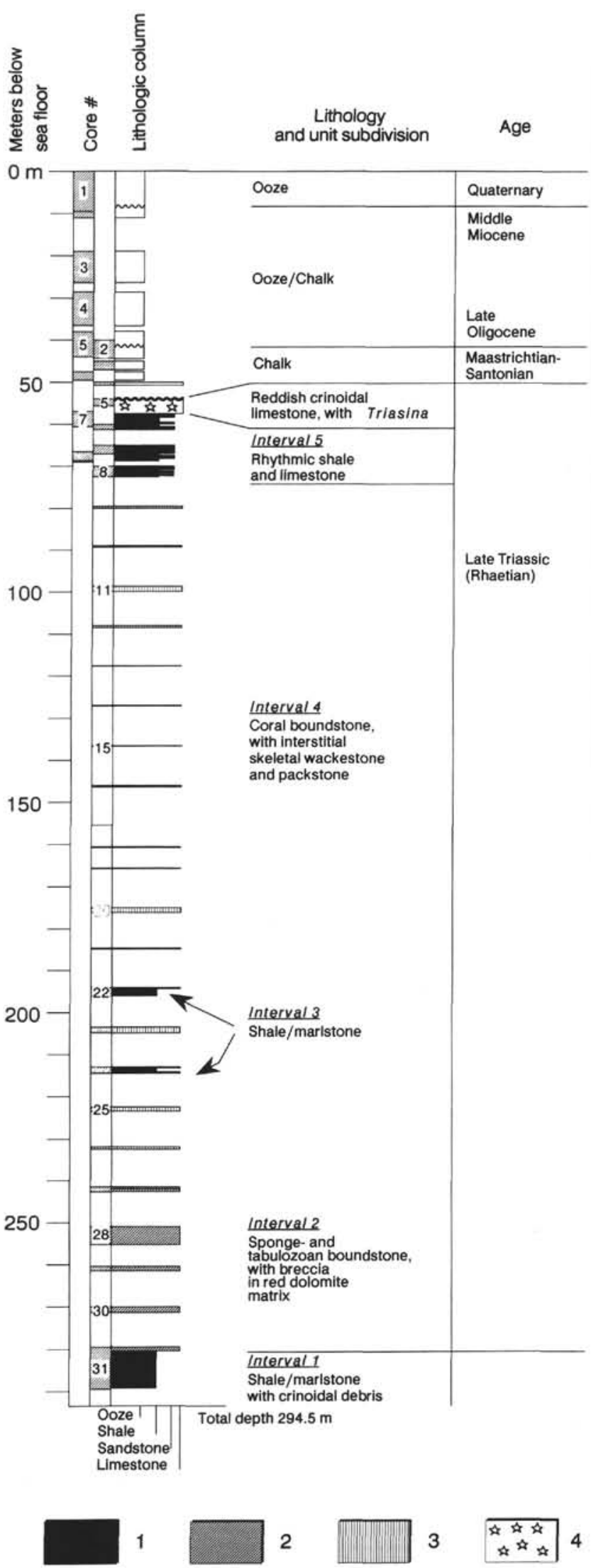

Figure 6. Lithologic column, Site 764. Major lithologic types and units are referred to in the text. 
A

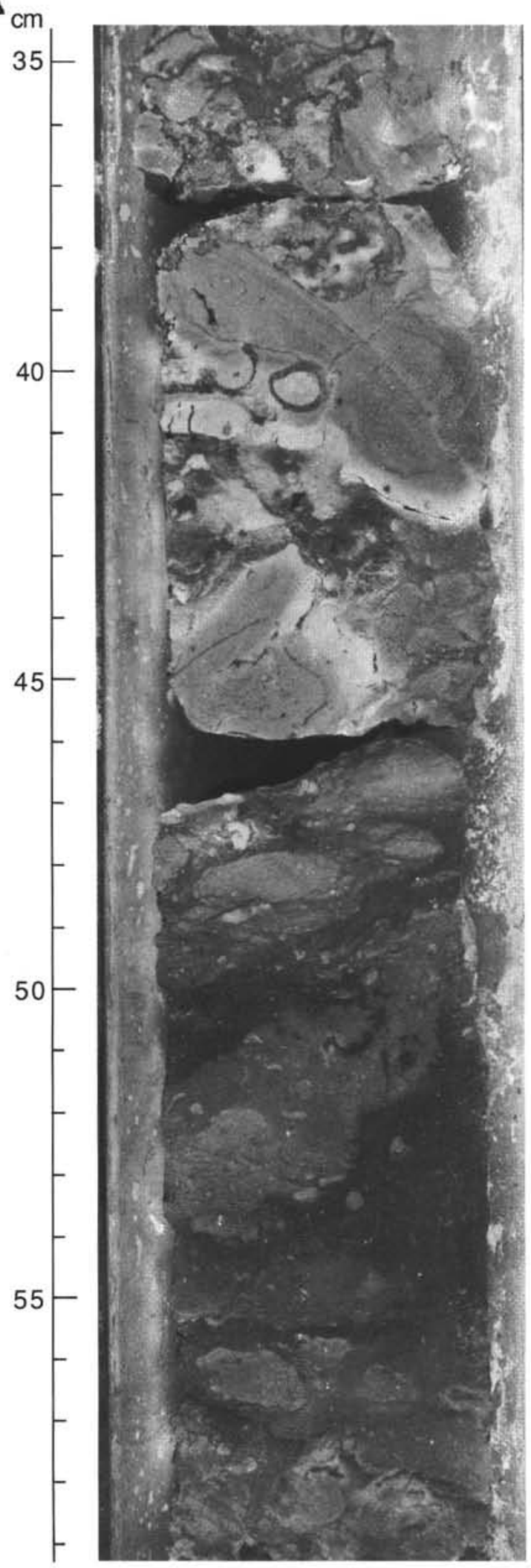

B

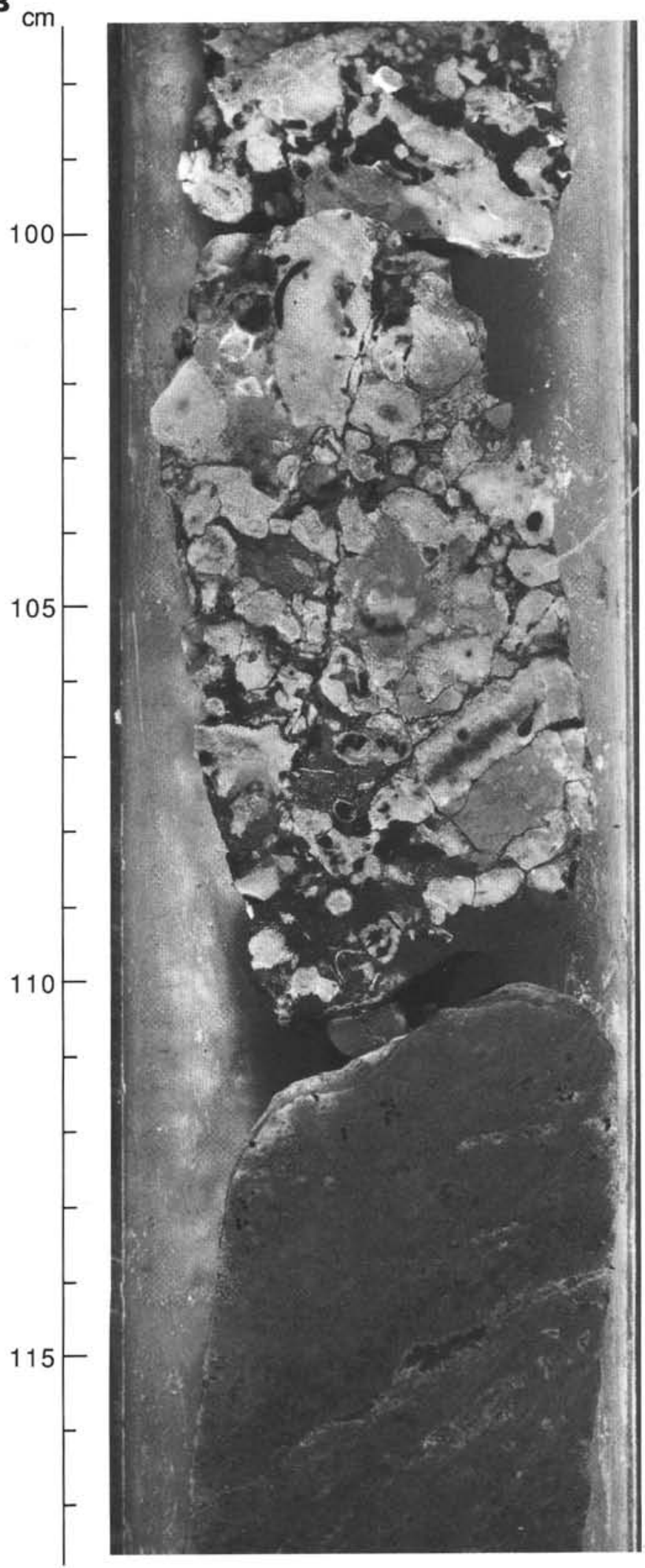

Figure 7. A. Red nodular "floatstone" consisting of pink fossiliferous micrite nodules in a microstylolitic, dolomitized mudstone matrix (Section 122-764B-28R-2, 34-59 cm). Note the remarkable structural similarity to the Rosso Ammonitico, a classical marine condensed facies of the Tethyan Jurassic (Ameur and Elmi, 1981). B. Boundstone (rudstone) consisting of an in-situ-grown community of chiefly sponges $(85-111 \mathrm{~cm}$ ) in a dark red dolomitic mudstone matrix (Section 122-764B-28R-3, 97-118 cm). This interval belongs to the lowermost part of the sponge community association. 
as the frame-filling matrix described previously, with large variations in the percent of the allochemical fraction, from a few units to a few tens of a percent. Poorly sorted oolitic layers and bioclastic calcarenite (grainstone) formed by a coarse-grained mixture of sponge, brachiopod, mollusk, and echinoderm debris are subordinate sediment types. Superficial ooids are formed by a bioclast nucleus coated by a thin, micritic cortex. Cement in the intergranular pore space consists of a thin, isopachous, acicular fringe and clear blocky spar.

Intraclast breccias may be derived from reworking of the local sediment, with the calcarenite transported from a nearby, possibly shallower source. Both products might be the effect of storm-induced turbulence in the environment of deposition.

\section{Interval 3}

Shelf, rhythmic shale, and biogenic carbonate unit (Cores $122-761 C-23 R$ through 122-761C-29R and 122-764B-22R through $122-764 B-26 R$ ). The red dolomitic horizon precedes a 120 - to 150 -m-thick shallow-water biogenic carbonate package, which has intervals of rhythmic shale and bioturbated clayey limestone in the lower $50 \mathrm{~m}$. At Site 761, the limestone just above the red dolomitic horizon is a light gray peloidalskeletal and coral-rich calcarenite (packstone and/or grainstone) with mollusk debris (commonly outsized fragments), thin bivalve shells, brachiopods, minor tabulozoans/bryozoans, and benthic foraminifers, including Trocholina, Lenticulina, and lagenids. At Site 764, coral and tabulozoan/bryozoan boundstone and fossiliferous packstone dominate, locally with coarse $(0.5-3 \mathrm{~mm})$ brachiopod, echinoderm (chiefly crinoid), and mollusk debris mixed with pelletal and skeletal micrite. Tabulozoans/bryozoans and coral may be bored by endolithic bivalves (Pl. 2, Fig. 2), and tabulozoans/bryozoans are seen to encrust a reef-building organism body. Thin-shelled bivalves are common and rarely dominate the bioclastic component. Foraminifers (lagenids, Vidalina sp.), calcareous sponge spicules, Solenopora fragments, and ooids are very rare in occurrence. Sediments show some dolomitization, varying from patchy dolomitization to the development of scattered rhombs. Iron oxide is commonly abundant as a precipitate in the pores of crinoid plates, in the intergranular pores of the rocks, and within dolomite crystals.

Isopachous dogtooth or acicular cement fringes fossil molds, intergranular pores in grainstone, and more rarely large (a few millimeters) sheltered cavities within coral branches. Late-stage blocky calcite may or may not be present. Primary porosity is high in the biogenic limestone at Site 764.

At Site 761 , the lower limestone horizon is overlain by some $40 \mathrm{~m}$ of rhythmically alternating, dark gray shale and limestone, whereas at Site 764, shaley interbeds are present within dominantly crinoidal and brachiopod-rich carbonates (packstone). Carbonate-rich lithologic types in the rhythmic unit at Site 761 include bioturbated, gray-colored, fossiliferous-skeletal wackestone and packstone; clay-rich sediments are darker and richer in organic matter (4\%-6\% total organic content). The fossil components consists of fine mollusk debris, thin whole bivalve shells, echinoderm ossicles, and brachiopod fragments. Brachiopod debris, calcareous sponge spicules, and terrestrial plant material tend to be more abundant in the finer, micritic lithologic types. Ooids, algal fragments (including Solenopora), and coral debris are minor or dominant components of some of the packstone. Benthic foraminifers (textulariid and valvulinid types), Triasina, lagenids and Lenticulina, calcispheres, and ostracodes are more or less common occurrences in both the grainy and micritic sediments. Calcareous sediments are patchily to pervasively dolomitized.

\section{Interval 4}

Shallow-water carbonate package (Cores 122-761B-31R through 122-761B-33R, 122-761C-11R through 122-761C-22R, and $122-764 B-9 R$ through $122-764 B-21 R$ ). A package of white to light gray limestone follows the shaley/marlstone unit at both Sites 761 and 764 . Recovery was minimal at both locations ( $<8 \%$ average); therefore, no assessment of the true composition of the lithologic column was possible based on the sampled material. However, the wireline log shows a steady low gamma-ray emission in the upper part of the Rhaetian section which we assume to correspond to a massive, homogenous carbonate package. The thickness of this unit is $73 \mathrm{~m}$ at Site 761 , and slightly more than $120 \mathrm{~m}$ at Site 764.

At Site 761 , carbonate rock types include oolitic and skeletal grainstone, fossiliferous wackestone, algal-laminated intervals with a red-soil coloration (Fig. 8), and subordinate algal and coral boundstone. Laminated "beach rock" formation, with fenestral porosity and birdseye structures (after gas bubbles), was also noted in the hand specimen, suggesting deposition above the water table. Megalodon bivalve shells or internal molds, branching hermatypic corals, and Triasina foraminifers are characteristic biotic components.

At Site 764, the characteristic lithology is a buff, locally pink-colored, coral bafflestone and framestone with a variety of interstice-filling fossiliferous, skeletal calcarenites (packstones and grainstones) and wackestones. Biota in the framestone-filling matrix consists primarily of mollusks, rare brachiopod and echinoderm debris, scattered algal fragments (Solenopora, Thaumatoporella), and tabulozoans/bryozoans, plus rare oncoids and micrite intraclasts. Benthic foraminifers include Triasina, rare Trocholina, miliolids, coiled arenaceous fragments, and Nautiloculina.

In the upper $40 \mathrm{~m}$ (Cores 122-764B-9R through 122-764B$12 \mathrm{R})$, corals are less abundant and sediments are a coarse- to medium- grained skeletal and pelletal packstone, containing outsized mollusk and echinoderm debris, rare tabulozoans/ bryozoans and calcareous sponge spicules, and among foraminifers, abundant Triasina, lagenids, Spirillina, a few Glomospira, Nautiloculina, Trocholina, and miliolids. Fine pelletal packstones with thin-shelled bivalve debris and abundant calcareous sponge spicules are also present.

The skeletal components are commonly bored and show a generally thick micrite envelope, which are common signs of bioerosion in a shallow-subtidal environment. Mollusk fragments only are leached and are cemented by isopachous dogtooth fringe and blocky spar. The lower biogenic carbonates (Cores 122-764B-13R through 122-764B-21R) are extremely porous with a range of primary intergranular, moldic, and dissolution porosity. Void space is lined by a thin fringe of dogtooth and acicular marine cement. Some of the moldic cavities show asymmetric cement growth, probably related to the mineralogical composition and crystal fabric of the substrate. Sediments become mildly dolomitized downsection.

\section{Interval 5}

Shaley and crinoidal drape (Cores 122-764A-6R, 122-764A$7 R$, and $122-764 B-4 R$ through $122-764 B-8 R$ ). The reefal limestone is conformably overlain by some $20 \mathrm{~m}$ of cyclically alternating dark gray-yellowish calcareous claystone and bioturbated clayey limestone (Chondrites), containing nannofossils, benthic foraminifers (lagenids), thin-shelled bivalves, scattered crinoid ossicles, calcareous sponge spicules, and abundant plant fragments (1\%-4\%). 


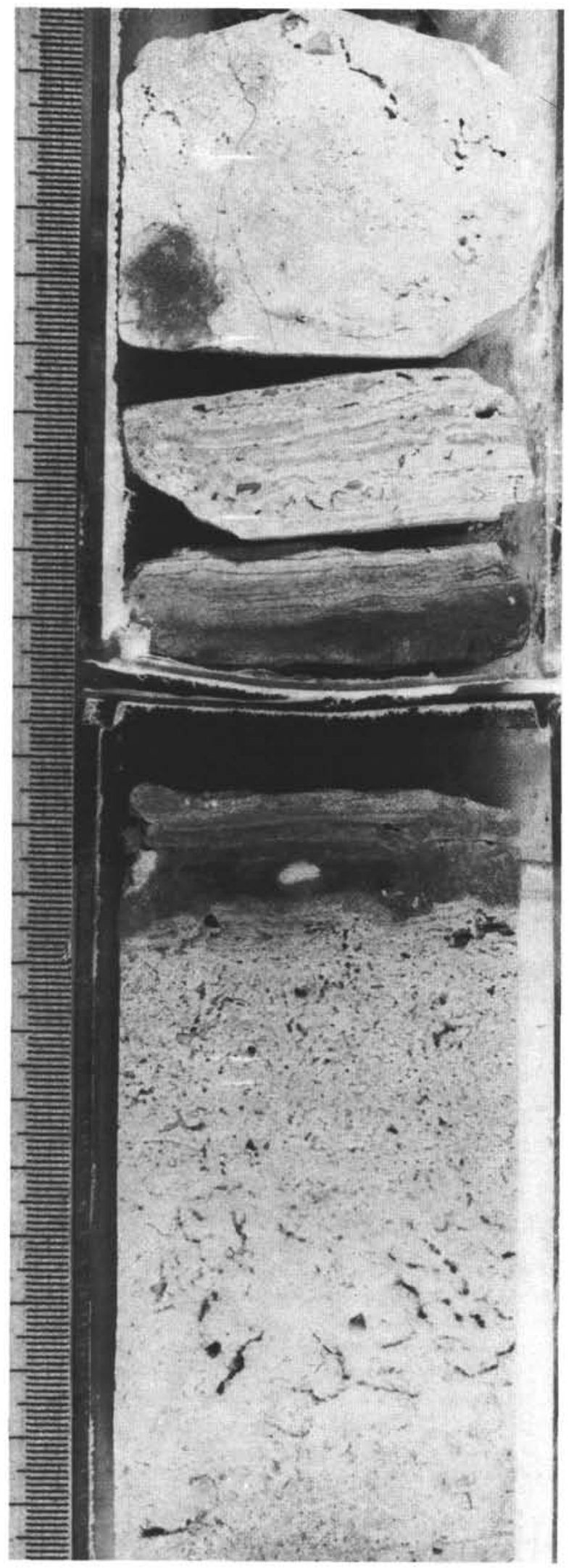

Figure 8. Buff-colored limestone with fenestral voids (birdseye structures), overlain by algal-laminated sediments with a reddish coloration, probably derived by subaerial exposure and soil formation (Sections 122-761B-33R-1, 130-150 cm, and 122-761B-33R-CC, 0-20 $\mathrm{cm})$. Scale in centimeters.
This unit is terminated by a $<8$-m-thick Triasina-rich, slightly nodular crinoidal calcarenite (packstone) and biomicrite (wackestone), with thin-shelled bivalve debris. Among the benthic foraminifers, lagenids (Nodosaria) and characteristic Lenticulina are noteworthy. Allochems are coated by iron and manganese oxides and hematite-rich anastomosing microstylolite seams commonly outline elongate nodule structures in the sediment. Ghosts of parallel and oblique laminae are visible. Mn-oxide grains and stringers are noticeable (Fig. 9).

At Site 761, none of these facies was sampled, but wireline logs show a distinctive high-gamma-ray excursion above the carbonate interval which we assume to correspond to the rhythmic shale and limestone of Site 764.

\section{FOSSIL COMMUNITIES OF WOMBAT PLATEAU "RHAETIAN" SEQUENCE}

We use here the term "community"' in the sense of Stanton and Flügel $(1987,1989)$ for Late Triassic reef communities of the Northern Calcareous Alps. These authors described these communities "on the basis of larger and skeletonized taxa." Moreover, they stated that "although they form only a small part of the community numerically and taxonomically, they are truly the dominant components of it. They comprise the bulk of the community biomass, channel most of the energy flow through the community . ... and determine its morphology."

The Late Triassic reef-building communities of the Wombat Plateau have been studied almost exclusively from samples from Site 764 , where the quantitative predominance of frame-building organisms has permitted the identification of three distinctive fossil communities: (1) a sponge community, (2) a hydrozoan-tabulozoan community, and (3) a coral community. The vertical distribution of taxa and fossil assemblages at Site 764 is shown in Table 1. At Site 761, fossil communities were not sufficiently characterized because of the presence of scattered corals only at certain intervals, identifying an impoverished, low-diversity assemblage of platform-interior environments.

A limit of this study derives from the impossibility of determining the areal distribution of fossil assemblages, the geometry of colonies, and in most cases the size and morphology of individual organisms. Thus, the taxonomic determination of certain taxa (especially sponges and hydrozoans) is inevitably imprecise. On the other hand, imaging of the large-scale pinnacle geometry of the buildups (Fig. 2) was furnished by high-resolution seismic profiles (Williamson et al., 1989), and continuous coring provided a good control on the vertical distribution of the fossil species. It is on the vertical evolution of fossil communities that we base our reconstruction of reef development at the Wombat Plateau margin.

\section{Sponge Community}

The sponge community is repeated 3 times in the lower 40 $\mathrm{m}$ of the succession at Site 764 (Sections 122-764B-27R-1, 33 $\mathrm{cm}$, through 122-764B-30R-1), alternating with the hydrozoantabulozoan assemblage (Table 1). In the lower part of this interval, above the dark gray shale and marlstone, there is a biogenic rubble consisting of sphinctozoans (Cryptocoelia?, Salzburgia; Pl. 1, Fig. 1), inozoans (chiefly Peronidella), fragments of Retiophyllia branches, small tabulozoans/bryozoans, juvenile gastropods, brachiopods, bivalves, and crinoidal debris. Upward in the same unit, boundstones of erect, branching columnar sponges become dominant.

In the first sponge-rich interval (Sections 122-764B-28R-2, $116 \mathrm{~cm}$, though 122-764B-30R-1) sphinctozoans and Salzburgia are dominant with respect to inozoans, especially 


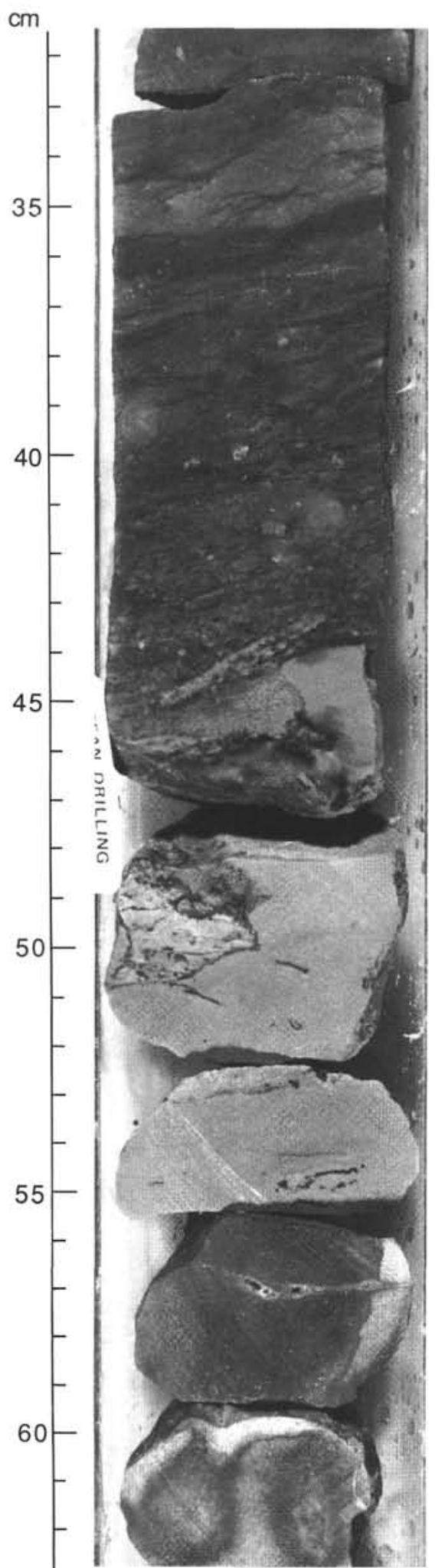

Figure 9. Crinoidal calcarenite impregnated with iron oxide (36-45 $\mathrm{cm})$ overlying gray clayey limestone $(45-56 \mathrm{~cm})$ at the top of the Rhaetian shallow-water limestone and dolomite (Section 122-764A$7 \mathrm{R}-1,31-63 \mathrm{~cm})$. Very finely divided iron oxide minerals are concentrated as insoluble residues along dissolution seams (microstylolites), which confer a nodular appearance to the sediment $(31-45 \mathrm{~cm})$. Coarse crinoid ossicles appear as undissolved relic fragments. Note dark manganese oxide stringers at $45-50 \mathrm{~cm}$.
Peronidella, and Sestrostomella (Pl. 1, Fig. 2). Small tabulozoans/bryozoans are also important and hydrozoans and serpulids are subordinate. Tabulozoans, hydrozoans, and serpulids commonly encrust columnar sponge bodies (PI. 2, Fig. 1), whereas tabulozoans are usually attacked by boring endolithic mollusks. Endolithic mollusk shells are commonly observed fossilized in situ within the boring cavity (Pl. 2, Fig. 2). "Microtubes" are rare.

In the second sponge-rich interval (Sections 122-764B$28 \mathrm{R}-1,80 \mathrm{~cm}$, to $122-764 \mathrm{~B}-28 \mathrm{R}-2,34 \mathrm{~cm}$; Table 1), sphinctozoans dominate in the lower part, but decrease steadily upward as inozoans (Molengraaffia) and other unidentifiable calcisponges become more common. As with the sphinctozoans, tabulozoans/bryozoans also become subordinate compared with the previous interval, whereas hydrozoans and serpulids still occur. With the exception of the inozoans, which are never encrusting, and the tabulozoans, which are never colonized, all other organisms are both encrusting and encrusted.

In the upper sponge-rich interval (Section 122-764B-27R-1, 33-107 cm; Table 1) the community is impoverished, consisting of Molengraaffia, sphinctozoans, and unidentifiable inozoans. Tabulozoans/bryozoans also diminish. Associated sediments are biomicrites (mudstones and wackestones) with sponge spicules, foraminifers, and fine-grained mollusk debris. A characteristic common to the three biofacies intervals is the absence of spongiomorphids, which instead occur as components of the hydrozoan-tabulozoan community described in the following section.

\section{Hydrozoan-Tabulozoan Community}

Fossil assemblages pertaining to a hydrozoan-tabulozoan community alternate with the sponge associations in the lower part of the succession (Sections 122-764B-28R-2, 38-111 cm, and $122-764 \mathrm{~B}-27 \mathrm{R}-1,114 \mathrm{~cm}$, to $122-764 \mathrm{~B}-28 \mathrm{R}-1,74 \mathrm{~cm}$ ) and occur as discrete intervals within the coral communities (Sections 122-764B-26R-1, $40 \mathrm{~cm}$, to $122-764 \mathrm{~B}-27 \mathrm{R}-1,3 \mathrm{~cm}$, 122-764B-23R-1, $49 \mathrm{~cm}$, to 122-764B-24R-1, $126 \mathrm{~cm}, 122-$ 764B-22R-1, 4-9 cm, and 122-764B-14R-CC, $2 \mathrm{~cm}$, to $122-$ $764 \mathrm{~B}-18 \mathrm{R}-\mathrm{CC}, 7 \mathrm{~cm}$ ) (Table 1). This assemblage is characterized by the absence of sponges and by the dominance of small and large tabulozoans and spongiomorphids (Stromatomorpha rhaetica and Spongiomorpha ramosa; Pl. 1, Fig. 3). Large tabulozoan genera are very similar to Lovcenipora (Pl. 2, Fig. 4) described by Sadati (1981) from the Hohe Wand, southeast of Vienna, Austria, and by Vinassa de Regny (1915) from Timor, Indonesia.

Hydrozoans, including the genus Disjectopora (PI. 1, Fig. 4), are subordinate and the presence of Astreomorpha crassisepta and Astreomorpha confusa is sporadic. Tabulozoans/ bryozoans are commonly encrusted by other species of tabulozoans, Stromatomorpha, and serpulids and occur as both globose (head-shaped) and ramified colonies. Spongiomorphids are observed encrusted by tabulozoan/bryozoan colonies and serpulids.

The upper intervals of these faunal communities (Sections 122-764B-22R-1, 4-9 cm, and 122-764B-14R-CC, $2 \mathrm{~cm}$, to 122-764B-18R-CC, $7 \mathrm{~cm}$ ) are characterized by a decrease of spongiomorphids and hydrozoans. These associations, unlike the classic tabulozoan/hydrozoan fossil assemblages of the Northern Calcareous Alps (Stanton and Flügel, 1987, 1989), are lacking sponge representatives (sphinctozoans and inozoans) and corals are virtually absent.

\section{Coral Community}

A community of little-diversified corals is present from Sections 122-764B-9R-1, $20 \mathrm{~cm}$, to 122-764B-27R-1, $24 \mathrm{~cm}$, 
alternating with sediment horizons bearing fossil assemblages ascribed to the hydrozoan-tabulozoan community. The coral community is typified by small coral colonies embedded in micrite-rich lithologic types. In the lower intervals (Sections 122-764B-27R-1, 3-24 cm, and 122-764B-24R-1, $127 \mathrm{~cm}$, to 122-764B-25R-1, $99 \mathrm{~cm}$ ) branching colonies of Margarosmilia gr. charlyana (Pl. 3, Fig. 1), Retiophyllia paraclathrata (Pl. 3, Fig. 2), and Retiophyllia sp. are dominant, associated with rare spongiomorphids, tabulozoans, and Astreomorpha crassisepta. In the upper three intervals (Sections 122-764B23R-1, 9-50 cm, 122-764B-18R-CC, $14 \mathrm{~cm}$, to $122-764 \mathrm{~B}-$ $22 \mathrm{R}-1,1 \mathrm{~cm}$, and $122-764 \mathrm{~B}-9 \mathrm{R}-1,20 \mathrm{~cm}$, to $122-764 \mathrm{~B}-14 \mathrm{R}-\mathrm{CC}$, $2 \mathrm{~cm}$ ) specimens of Astreomorpha crassisepta (Pl. 3, Fig. 3) and Astreomorpha confusa (Pl. 3, Fig. 4) increase in abundance. These are associated with small colonies of unidentifiable thamnasteroid corals, Chondrocoenia schafhaeutli, and rare Retiophyllia colonies. In these upper intervals, fragments of unidentifiable corals are abundant, tabulozoans (only large tabulozoans are present) become overall rather rare, and spongiomorphids virtually disappear.

\section{FOSSIL COMMUNITIES AND SEDIMENT-TYPE ROCK UNITS}

The strict dependance of fossil communities on the lithologic units with which they are associated emphasizes the notion that the evolution of fossil populations echoes the changes in the sediment types and the environments of deposition.

The sponge community is characteristic of the interval between Cores 122-764B-27R and 122-764B-30R, which we identified as a condensed, red-colored, dolomitic unit. It also probably corresponds to the thin unit of biogenic rubble with red dolomitic pockets at the top of Core 122-761C-30R, although shipboard sampling and resin impregnation treatment of this characteristic interval prevented specific sampling of the biota for community comparison.

The coral community spans the interval from Core 122 764B-9R through Section 122-764B-27R-1 and coincides with the more typical shallow-water carbonate intervals 3 and 4, with Retiophyllia assemblages dominant in the lower part, in association with shales and clayey limestone interbeds (interval 3, "shelf, rhythmic shale, and biogenic carbonates"). Astreomorpha dominates in the uppermost shelf carbonates (interval 4). There is a dramatic change in the fossil assemblages between Samples 122-764B-27R-1, 22-24 cm, and 122-764B-27R-1, 33-37 cm, close to where the sediments change from dolomitic to calcareous and turn from red to white. We interpret this change as a sudden coral bloom following a period when the seafloor was stabilized by sponges and had gradually shallowed to an optimum depth at which colonies of corals could extensively grow. An alternative explanation of the red-colored dolomitic unit as a subaerial exposure horizon (Röhl et al., this volume) is discarded, based on geochemical evidence (Sarti and Kälin, this volume) and on the presence of in-situ-grown fossil constituents, suggesting a highly oxygenated submarine environment.

A discussion on the significance of changing communities follows.

\section{FOSSIL COMMUNITIES AND REEF PALEOECOLOGY}

The fossil communities we identified show a vertical evolution, from sponge-dominated at the base of the sequence, to coral-dominated in the upper half, in association with ubiquitous hydrozoan-tabulozoan assemblages.

Sponge and hydrozoan-tabulozoan communities have been described by Stanton and Flügel $(1987,1989)$ as constituting the reef tract in the Upper Triassic of the Northern Calcareous Alps. The lime mudstone facies there dominate and are developed on the depositional slopes of the mounds, at different stratigraphic levels and bathymetric positions.

This model is relevant, as we have reason to believe that the sponge buildups of the lower Wombat sequence, resting on a crinoid-rich unit with redeposited beds of turbiditic origin, also formed in rather deep water, in a low-energy setting dominated by fine sediments (wackestones and mudstones). The sponge community acted to baffle the sediment without, however, being a substantial sediment source itself, as it contributed only a small fraction of the biogenic debris to its locale. We surmise that the growth of the sponge-dominated community represented the first colonization of a mobile ground, at a time of limited sediment supply. The associated iron oxide-rich sediments indicate sediment starvation and a highly oxidizing environment.

The coral community replaces the sponge-rich community upward, is associated with ubiquitous tabulozoans/hydrozoans, and is interbedded with marine shale/limestone in the lower part (interval 3). The coral community is comparable to the Thecosmilia or "high-growing coral" community of Stanton and Flügel (1987), as Retiophyllia (Thecosmilia Auctt.) is the most common genus, particularly in the lower two intervals. The Retiophyllia association is also reported from the basinal Kössen Beds and from the facies overlying the Steinplatte reef (Tyrol, Austria) (Stanton and Flügel, 1989), as well as in the more protected reaches of the reefal strata (reef patches) described from Adnet, near Salzburg, Austria (Schäfer, 1979).

On the Wombat Plateau, the Retiophyllia-dominated communities occur within crinoid-rich, marine shales of an open marine low-energy environment, but change abruptly into Astreomorpha and thamnasteroid coral assemblages, associated with sediments of a more explicit shallow-subtidal character.

At Site 761, where sediments suggest a shallower to nearly emergent depositional setting (platform interior), coral buildups are missing and replaced by internal lagoon biota (Megalodon) with episodes of intertidal deposition (algal mats) and supratidal soil formation (Fig. 8). Examples of leaching and cementation in the intertidal zone (beach rock) are noticeable.

To our knowledge, the geographic distribution of Upper Triassic reefal facies in the Tethys is not delineated with great detail. Reports of Norian and Rhaetian coral-bearing strata are, among other localities, from Timor, Indonesia, where Vinassa de Regny (1915) described some 57 species of predominantly sphinctozoans, hydrozoans, and colonial and solitary corals of a remarkable Alpine affinity from the eastern Indonesian islands (Wanner, 1931; Wilckens, 1937), south China, and the Thailand/Burma border (Gregory, 1930); from some western Himalayan localities (Diener, 1908; Dronov et al., 1982; Bhargava and Bassi, 1985); and from the Northern Calcareous Alps (see the comprehensive overview in Flügel, 1982, and references therein). Some of the Spiti-Kinnaur coral-bearing formations include spongiomorphids, tabulozoans, and hydrozoans among the biotic components and show astounding similarities to the Australian examples in the sediment types, vertical zonation, buildup geometry (coral knoll reefs), and overall depositional setting ("patch reef formed in a wide reef area of moderate energy, with some protected parts," Bhargava and Bassi, 1985).

Nevertheless, the systematics of the biogenic components of these reefal strata are usually too poorly known to establish relationships among fossil assemblages and evaluate regional paleoecology and paleogeographic provinces. We have discussed in the preceding the extent of the similarities between the northwest Australian and Alpine fossil groups we used for comparison, which are considerably better known. Despite 
Table 1. Vertical distribution of macrofossil taxa at Site 764.

\begin{tabular}{|c|c|c|c|c|c|c|c|c|c|c|c|c|c|c|c|c|c|c|c|c|c|}
\hline Sedimentological Units & \multicolumn{21}{|c|}{ Red dolomitic biogenic hard-ground } \\
\hline Core & 30 & 29 & & & & & & & 28 & & & & & & & & & & & 27 & \\
\hline $\begin{array}{l}\text { Section } \\
\text { Interval (cm) }\end{array}$ & {$\left[\begin{array}{l}1 \\
13 \\
48\end{array}\right.$} & & 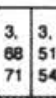 & \begin{tabular}{|l|}
3 \\
43 \\
45 \\
45
\end{tabular} & \begin{tabular}{|l|l|l}
3 & 3 \\
28 & 3 \\
30 & 24 \\
20 &
\end{tabular} & & & & & & & & & & & & & $\begin{array}{ll}105 \\
105 \\
007\end{array}$ & & & $\begin{array}{ll}1 \\
3 \\
3 \\
37 \\
37\end{array}$ \\
\hline $\begin{array}{l}\text { Salzburgia } \\
\text { Sphinctozoans }\end{array}$ & $P$ & $P$ & P & $P$ & P:P & IF & & & 4 & $P$ P & & & $f$ & & $F$ & & & $P P$ & & & \\
\hline $\begin{array}{l}\text { Sestrostomella } \\
\text { Peronidella } \\
\text { Inozoans } \\
\text { Molengraaffia } \\
\text { Calcisponges }\end{array}$ & $P$ & $P$ & $P$ & & $P$ & & & & & P & & & & $P$ & & & & & is & $\mathrm{P}$ & \\
\hline $\begin{array}{l}\text { Tabulozoans / Bryozoans } \\
\text { Stromatomorpha rhaetica } \\
\text { Spongiomorpha ramosa } \\
\text { Spongiomorphids } \\
\text { Disjectopora } \\
\text { Hydrozoans }\end{array}$ & PI & & $P$ & $P$ & $P$ & & $r$ & & & $P$ if & P & & 8 & & Pis & & $\left(\mathrm{P}^{2}\right.$ & $P$ & ב & Fe & $B$ \\
\hline $\begin{array}{l}\text { Retiophyllia sp. } \\
\text { Retiophyllia paraclathrata } \\
\text { Margarosmilia gr. charlyana } \\
\text { Astreomorpha crassisepta } \\
\text { Astreomorpha confusa } \\
\text { Chondrocoenia schafhaeutli } \\
\text { Thamnasteroid corals } \\
\text { Other corals }\end{array}$ & $\mathrm{P}$ & & & & & & & & & & & & & & $P$ & & & & & & \\
\hline
\end{tabular}

$$
\mathrm{P}=\text { Present }, \mathrm{F}=\text { fragments, } \mathrm{B}=\text { Branching Forms }
$$

objective difficulties in tying ecologically fossil assemblages from different localities, we believe that their regional distribution and established affinity is of a certain relevance in corroborating the notion that these reefs could have represented a widespread facies belt along the Tethys southern margin during the Late Triassic (Fig. 3).

\section{SUMMARY AND CONCLUSIONS}

A sequence of changing environments has been documented by studying sediment types and fossil communities of the Rhaetian strata of the Wombat Plateau, northwest Australia.

Sponge communities associated with intervals of tabulozoans/hydrozoans characterize the lower part of the biogenically built-up Wombat sequence. These are associated with crinoid-rich, red-colored ferruginous sediments of an open marine, quiet-water environment. The preceding unit of crinoidal and quartzose gray marlstone and calcarenite is commonly very coarse grained and consists of mechanically transported sediments of turbiditic origin. This unit is devoid of in-situ fossils, except for large mollusk and unidentifiable solitary coral fragments from a platform interior source. The turbiditic nature of many graded beds in this unit suggests a somewhat deeper setting and stronger basin relief than the underlying Norian deltaics. The depth of deposition of the turbiditic and red dolomitic sponge-rich units was at least that of the lower photic zone based on the habitat of the stalked crinoids (Roux et al., 1988).
The coral community assemblage constitutes the main core of a pinnacle reef complex, which is dominated by Retiophyllia in the lower part and by Astreomorpha associations (A. crassisepta, A. confusa) upward, following a shallowing of the environment of deposition. The sudden flourishing of corals probably reflected optimal depth conditions and the presence of a suitably stabilized seafloor by the preceding sponge growth. The alternation of the coral facies with hydrozoan-tabulozoan communities might suggest stages of reef growth (Röhl et al., this volume), but we do not agree with such an interpretation: the significance of ubiquitous hydrozoans and tabulozoans in this reef ecosystem is not known with sufficient accuracy to attribute these populations as indicators of growth cycles, rather we prefer to consider them as contributors within the reef ecosystem.

The topmost shaley unit with open marine biota and the red crinoidal limestone facies on top of the carbonate package document platform submergence within the lower photic zone.

The vertical development of fossil communities at Site 764 basically relates to depth variations, an interpretation that is corroborated by sediment characteristics and structures. An analogous depth signal is evidenced by biofacies variations in the Steinplatte, eastern Alps (Stanton and Flügel, 1989), where calcisponge mounds seem to be characterized by the occurrence downslope of spongiomorphids together with sphinctozoans and inozoans, whereas upslope they contain closely spaced sphinctozoans. As in the Wombat reef pinnacles, "Thecosmilia" thickets of the Steinplatte capping beds 
Table 1 (continued).

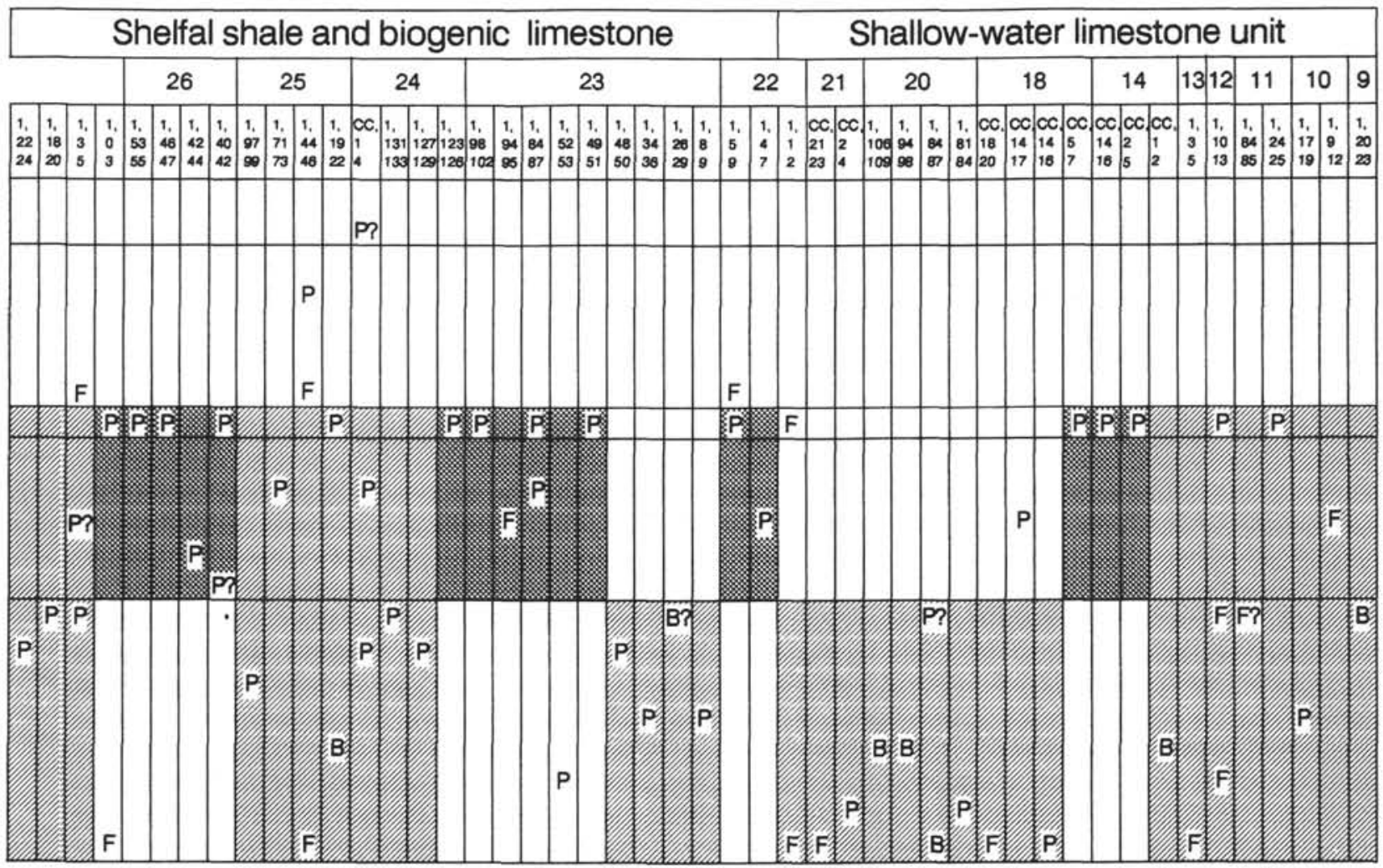

\section{Tabulozoan/Hydrozoan community}

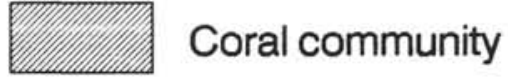

are concentrated in a shallower (upslope) position, at a water depth consistent with that commonly observed for other Upper Triassic buildups in the Tethyan realm (Piller, 1981; Stanton and Flügel, 1989).

A critical question concerns the significance of the pinnacle reef complex of the Wombat plateau as "ecologic reefs" or "stratigraphic reefs"-or more simply patch reefs (or reef patches, as the lowest size rank for bioconstructed bodies; Stanton and Flügel, 1987).

The essence of this long-lasting debate has been discussed by Stanton and Flügel (1987) and Stanley (1988). According to Stanton and Flügel (1987), frame-building corals and sponges may aggregate in extremely small patches, a few meters across, for which the term "Riffknospen," or reef patch, is suggested. These organic buildups do not erect a waveresistant framework, and hence they do not fall into the category of reefs in an ecologic sense. Sponge growth in the lower part of the Rhaetian sequence of the Wombat Plateau might correspond to this stratigraphic type of reef. In Stanton and Flügel's (1989) recent examination of the Upper Triassic limestone of the Steinplatte near Waidring at the Austrian/ German boundary - considered one of the classic examples of ancient reefs in an ecologic sense-they favored a "non-reefmodel," envisioning the deposition of bioclastic material on a carbonate ramp grading into a slope, as the dominant sedimentary process forming the buildup. According to Stanley (1988), the assumptions of Stanton and Flügel (1987) are ill founded and untenable, as the volumetric and ecologic importance of corals in the Steinplatte imply the development of a dense framework and a self-supporting biogenic structure, an indispensable requirement in the definition of reef. We do not think we have the conclusive elements to contribute to this debate, although the argument concerning the density of frame-building organisms is of some relevance to the definition of the Wombat buildups as fossil reefs. The community organization and the geometry and spatial arrangement of the organic buildups, as documented by geologic evidence along the northern edge of the Wombat Plateau, are instrumental in defining the Rhaetian pinnacle assemblage as a low-energy, bank-margin reef complex.

\section{ACKNOWLEDGMENTS}

We express our thanks to the Ocean Drilling Program staff, both shipboard and shore-based, for helpful assistance, and to the SEDCO crew, whose competent contribution made the Exmouth Plateau cruise a success. We wish to thank E. Flügel and B. Senowbari-Daryan, Erlangen, and E. Roniewicz, Warsaw, for discussions and suggestions. We are particularly indebted to C.G.St.C. Kendall and H. C. Jenkyns, who critically reviewed the manuscript and made suggestions for substantial improvements. Financial support was provided by the Consiglio Nazionale delle Ricerche, Rome (grants no. 89.04752.CT05, M. Sarti, and no. 89.04717.CT05, A. Russo), and NATO, Brussels 
(grant no. 154/89, M. Sarti). Their support is gratefully acknowledged. F. Bosellini wishes to thank M. B. Cita, of the Italian Commission for Ocean Drilling, Consiglio Nazionale delle Ricerche, for kindly supporting travel expenses.

\section{REFERENCES}

Ameur, M., and Elmi, S., 1981. Relations spatio-temporelles entre "Ammonitico Rosso," calcaires à "Zoophycos" et recifs corallines dans le Toarcien e la base du Jurassique moyen (Monts de Traras, Djebel Fillaoussense, Algérie NW). In Farinacci, A., and Elmi, S. (Eds.), Rosso Ammonitico Symp. Proc.: Roma (Edizioni Tecnoscienza), 9-25.

Bhargava, O. N., and Bassi, U. K., 1985. Upper Triassic coral knoll reefs: middle Norian, Spiti-Kinnaur, Himachal Himalaya, India. Facies, 12:219-242.

Diener, C., 1908. Ladinic, Carnic and Noric faunae of Spiti. Paleontologica Indica, Ser. 15, 5:1-157.

Dronov, V. I., Gazdzicki, A., and Melinikova, G. K., 1982. Upper Triassic reefs in the south-eastern Pamir range. Facies, 6:107-128

Exon, N. F., and Willcox, J. B., 1980. The Exmouth Plateau: stratigraphy, structure and petroleum potential. Bull.-Bur. Miner. Resour., Geol. Geophys. (Aust.), 199.

Falvey, D. A., and Veevers, J. J., 1974. Physiography of the Exmouth and Scott plateaus, Western Australia, and adjacent northeast Wharton Basin. Mar. Geol., 17:21-59.

Flügel, E., 1982. Evolution of Triassic reefs: current concepts and problems. Facies, 6:297-398.

Gregory, J. W., 1930. Upper Triassic fossils from the Burma-Siamese frontier: the Thaungyin Trias and description of corals. Rec. Geol. Surv. India, 63:155-167.

Montanaro-Gallitelli, E., Russo, A., and Ferrari, P., 1979. Upper Triassic coelenterates of western North America. Boll. Soc. Paleont. Ital., 18:133-156.

Piller, W., 1981. The Steinplatte reef complex, part of an Upper Triassic carbonate platform near Salzburg, Austria. In Toomey, D. F. (Ed.), European Fossil Reef Models. Spec. Publ.-Soc. Econ. Paleontol. Mineral., 30:261-290.

Roux, M., Bourseau, J. P., Bas, T., Dumont, T., de Graciansky, P. C., Lemoine, M., and Rudkiewicz, J. L., 1988. Bathymetric evolution of the Tethyan margin in the Western Alps (data from stalked crinoids): a reappraisal of eustatism problems during the Jurassic. Bull. Soc. Geol. Fr., 8:633-641.

Sadati, M., 1981. Die Hohe Wand: Ein obertriadisches Lagunen-Riff am Ostende der Nördlichen Kalkalpen (Niederösterreich). Facies, 5:191-264.

Schäfer, P., 1979. Fazielle Entwicklung und Palökologische Zonierung zweier obertriadischer Riffstrukturen in den Nördlichen Kalkalpen ("Oberrhät"-Riff-Kalke, Salzburg), Facies, 1:3-245.
Sengör, A.M.C., 1985. The story of Tethys: how many wives did Okeanos have? Episodes, 8:3-12.

Stanley, G. D., Jr., 1988. The history of Early Mesozoic reef communities: a three-step process. Palaios, 3:170-183.

Stanley, G. D., Jr., and Whalen, M. T., 1989. Triassic corals and spongiomorphs from Hells Canyon, Wallowa Terrane, Oregon. $J$. Paleontol., 63:800-819.

Stanton, R. J., and Flügel, E., 1987. Paleoecology of Upper Triassic reefs in the Northern Calcareous Alps: reef communities. Facies, 16:157-186.

Stanton, R. J., Jr., and Flügel, E., 1989. Problems with reef models: the Late Triassic Steinplatte "Reef" (Northern Alps, Salzburg/ Tyrol, Austria). Facies, 20:1-38.

Tollmann, A., and Kristan-Tollmann, E., 1985. Palaeogeography of the European Tethys from Paleozoic to Mesozoic, and the Triassic relations of the eastern part of Tethys and Panthalassa. In Nakazawa, K., and Dickins, J. M. (Eds.), The Tethys: Tokyo (Tokai Univ. Press), 3-22.

Vinassa de Regny, P., 1915. Triadische Algen, Spongien, Anthozoen und Bryozoen aus Timor. Palaeontol. von Timor, 4:75-118.

von Rad, U., and Exon, N. F., 1983. Mesozoic-Cenozoic sedimentary and volcanic evolution of the starved passive continental margin off northwest Australia. In Watkins, J. S., and Drake, C. L. (Eds.), Studies in Continental Margin Geology: AAPG Mem., 34:253-281.

von Stackelberg, U., Exon, N. F., von Rad, U., Quilty, P., Shafik, S., Beiersdorf, H., Seibertz, E., and Veevers, J. J., 1980. Geology of the Exmouth and Wallaby plateaus off northwest Australia: sampling of seismic sequences. BMR J. Aust. Geol. Geophys., 5:113-140.

Wanner, J., 1931. De Stratigraphie van Nederlandsch Oost-IndiëMesozoicum. Leidsche Geol. Meded., 5:567-610.

Wilckens, O., 1937. Korallen und Kalkschwämme aus dem obertriadischen Pharetronenkalk von Seran (Molukken). Neues Jahrb. Mineral. Geol. Palaeontol., 77:171-211.

Willcox, J. B., and Exon, N. F., 1976. The regional geology of the Exmouth Plateau. APEA J., 16:1-11.

Williamson, P. E., Exon, N. F., Haq, B. U., von Rad, U., O'Connell, S., and Leg 122 Shipboard Scientific Party, 1989. A Northwest Shelf Triassic reef play: results from ODP Leg 122. APEA J., 29:328-344.

Date of initial receipt: 10 June 1990

Date of acceptance: 18 March 1991

Ms 122B-140 


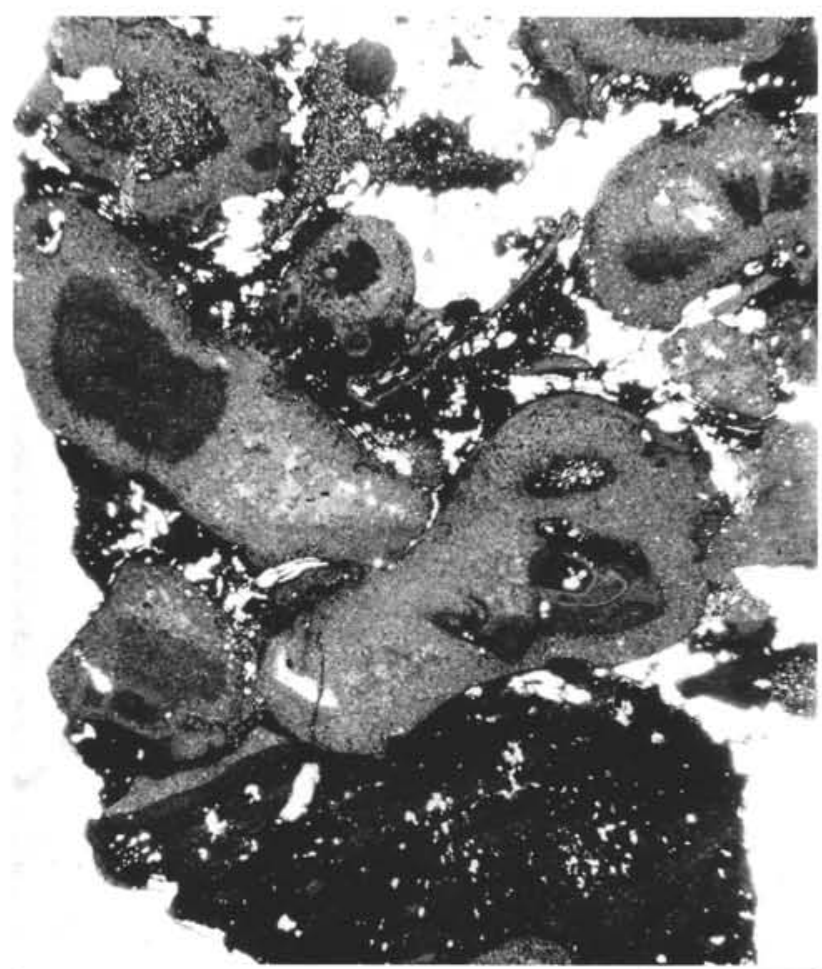

1

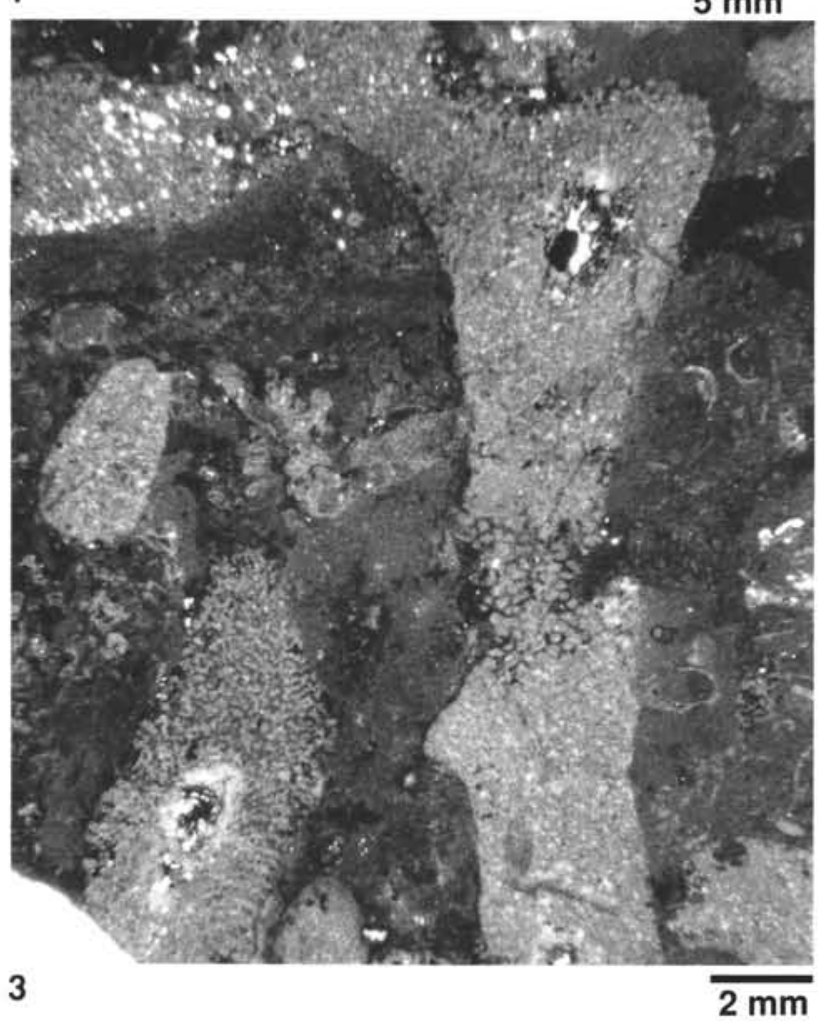

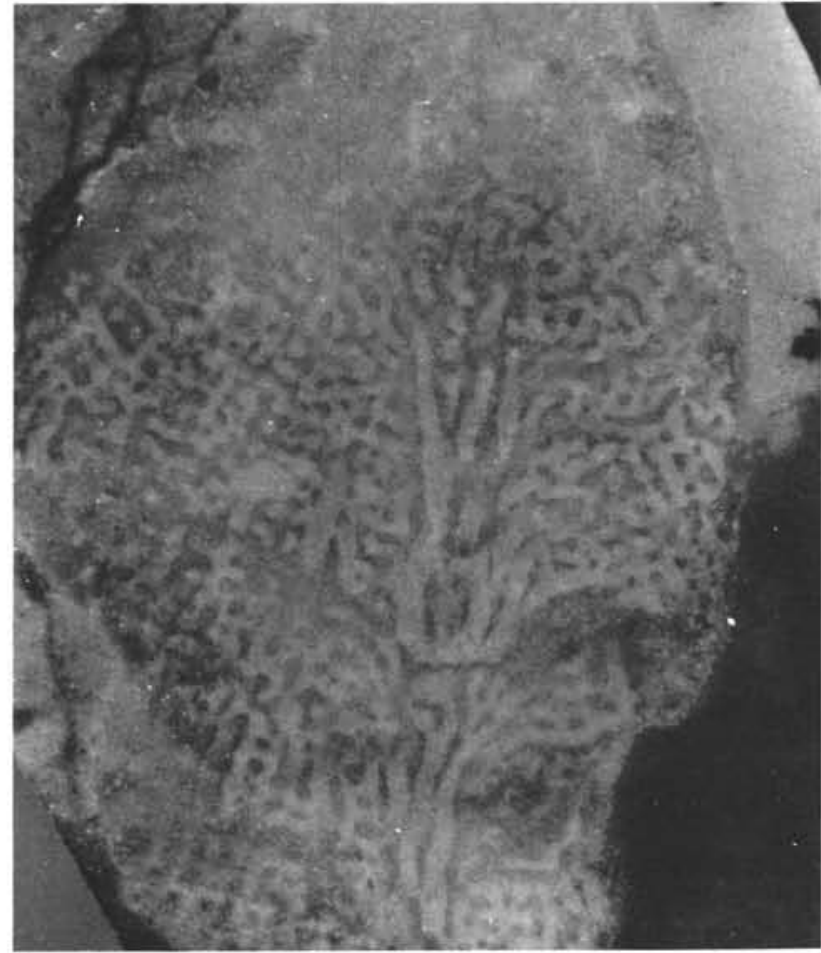

2

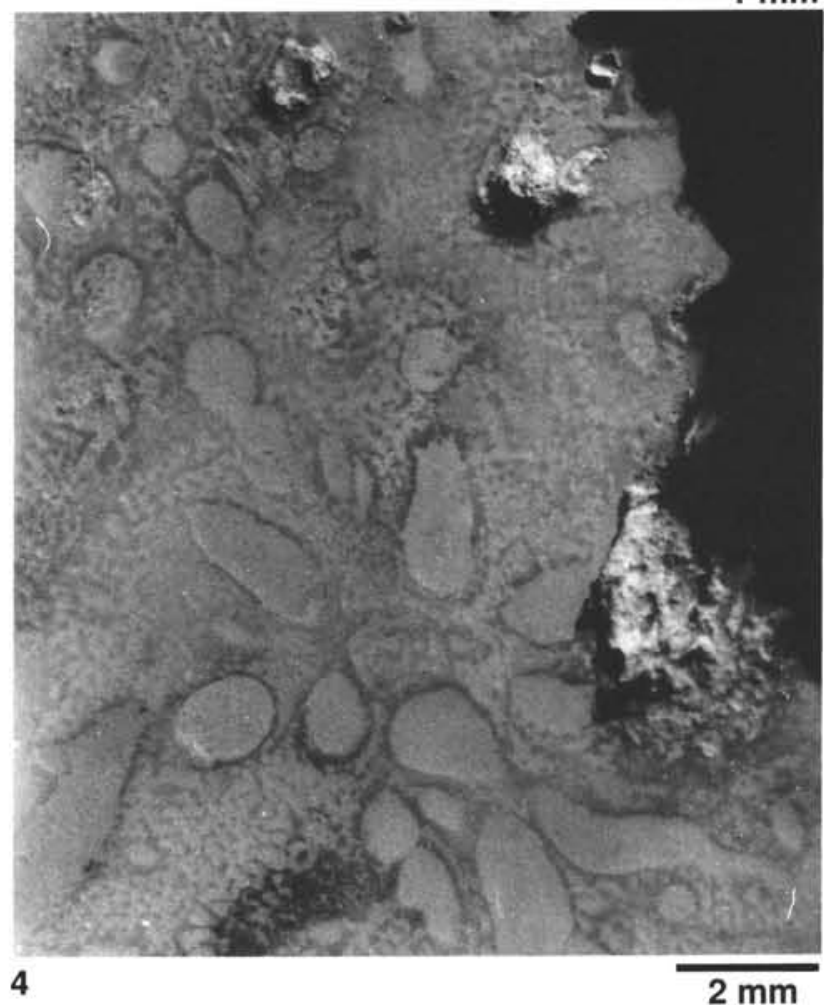

Plate 1. Specimens of sponges and hydrozoans (sponge and coral communities; Site 764). 1. Assemblage of Salzburgia sp. specimens embedded in dark (red) dolomitic matrix. Acetate peel. Sample 122-764B-28R-3, 24-29 cm. 2. Single specimen of Sestrostomella from the lowermost sponge community interval. Polished section. Sample 122-764B-28R-3, 51-54 cm. 3. Branching specimen of Spongiomorpha ramosa Frech, from an interval of the coral community, embedded in a dark-colored (reddish), fossiliferous dolomitic matrix. Acetate peel. Sample 122-764B-24R-CC, 1-4 cm. 4. Specimen of Disjectopora sp. Polished section. Sample 122-764B-26R-1, 42-44 cm. 


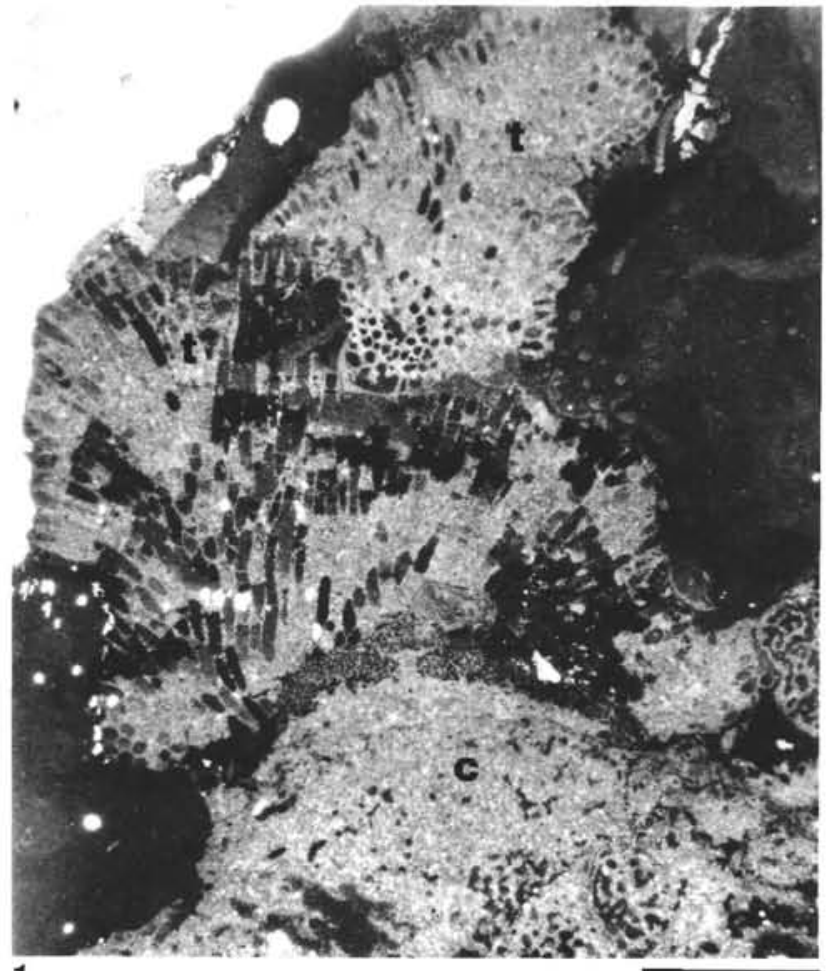

1

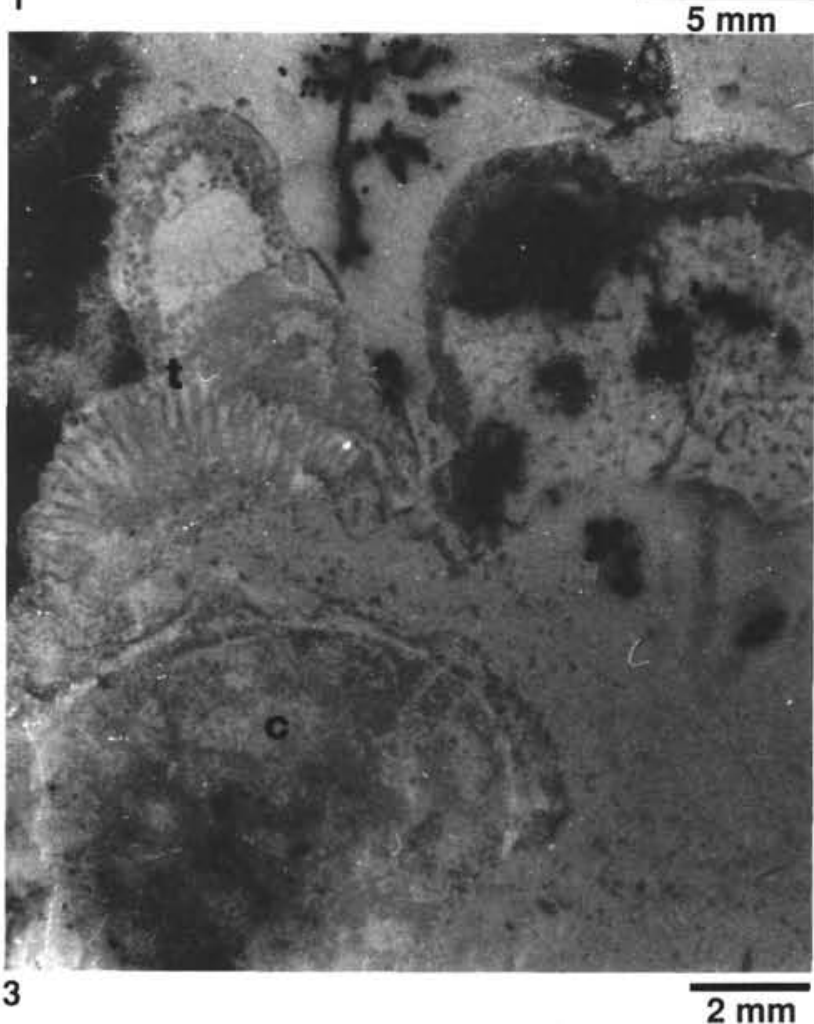

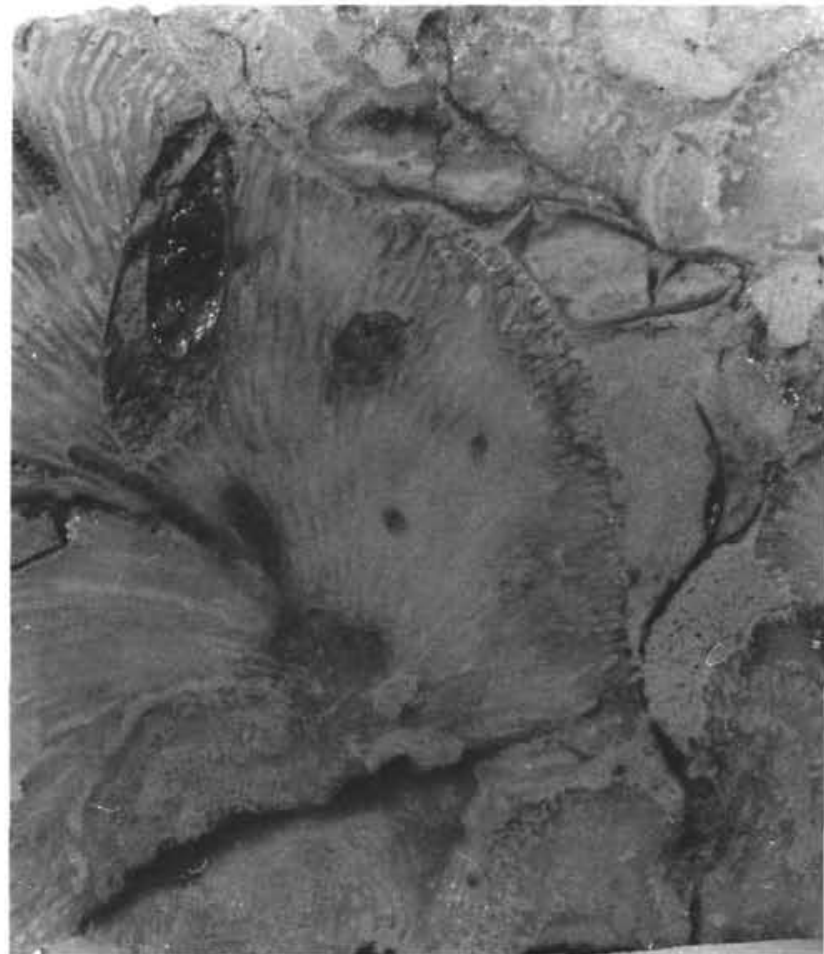

2

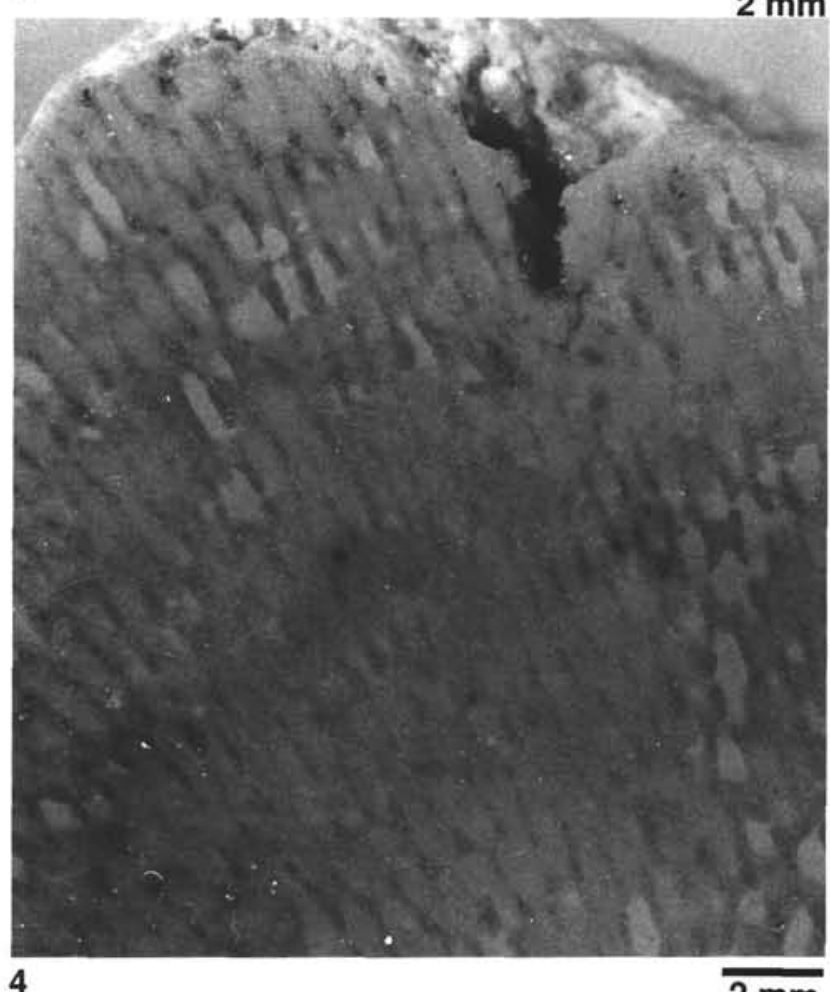

Plate 2. Specimens of tabulozoans/bryozoans (hydrozoan-tabulozoan community; Site 764). 1. Encrusting tabulozoan/bryozoan colony ( $t$ ) on a calcisponge (c). The dark matrix is red, ferruginous fossiliferous microcrystalline dolomite. Acetate peel. Sample 122-764B-28R-1, $40-42 \mathrm{~cm}$. 2. Tabulozoan/bryozoan colony bored by an endolithic mollusk. Polished section. Sample 122-764B-28R-3, 28-30 cm. 3. Encrusting foraminifers and tabulozoan/bryozoan colony $(\mathrm{t})$ on calcisponge (c). Polished section. Sample 122-764B-28R-3, 51-54 cm. 4. Large tabulozoan (cf. Lovcenipora). Transverse polished section. Sample 122-764B-24R-1, 123-126 cm. 

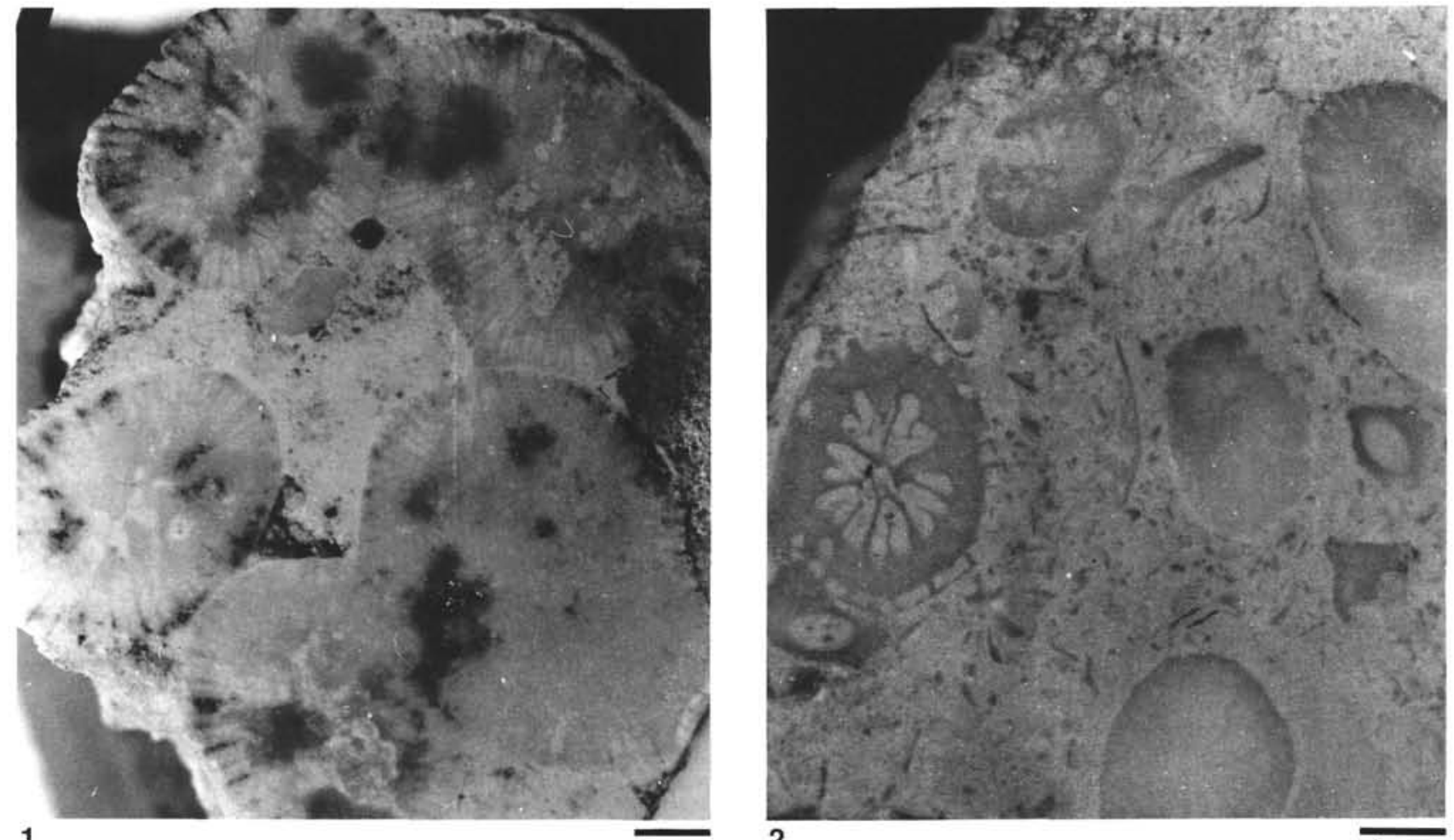

2

$1 \mathrm{~mm}$
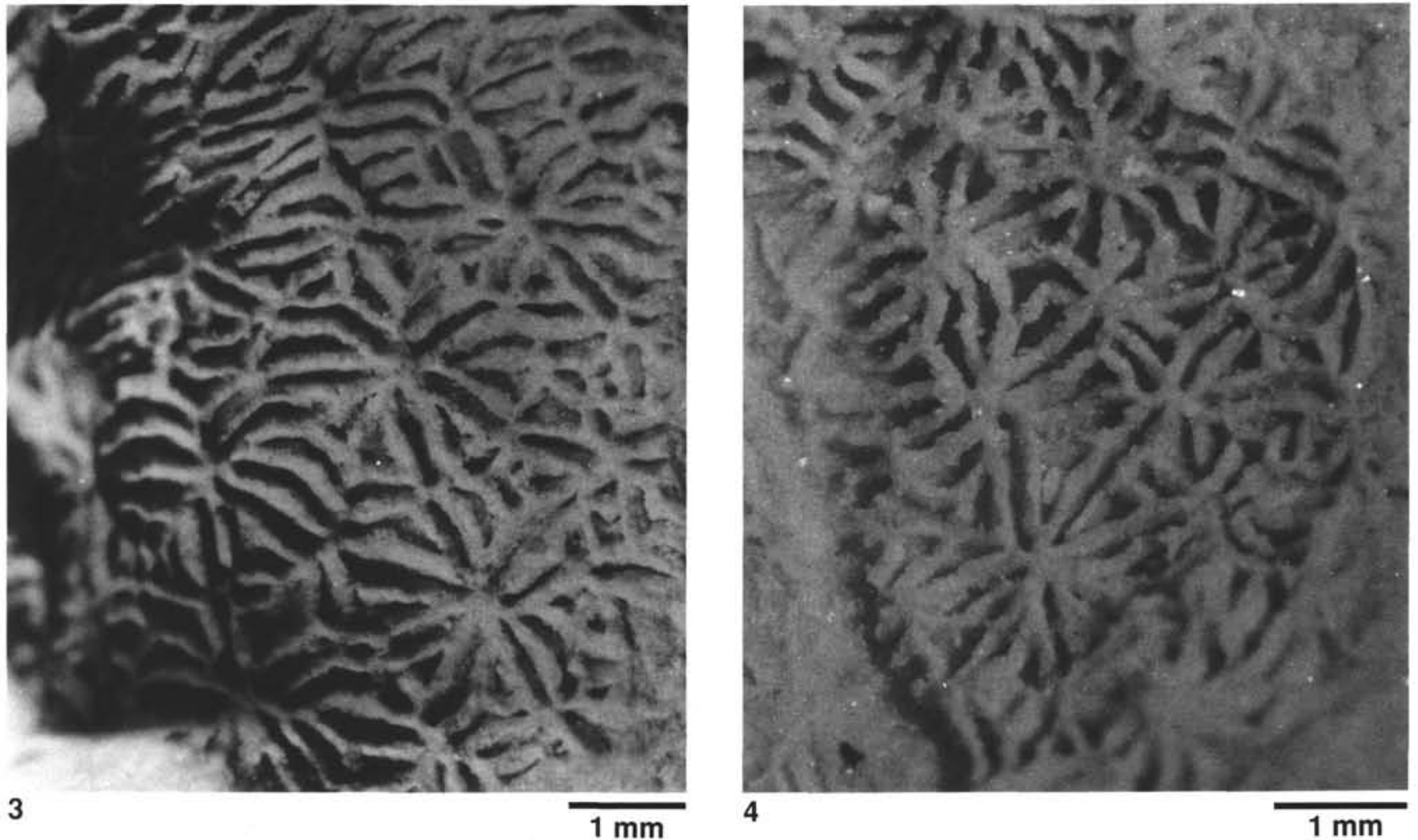

Plate 3. Coral specimens (coral community; Sites 761 and 764). 1. Dendroid colony of Margarosmilia gr. charlyana (Frech). Matrix is pelletal fossiliferous micrite. Polished section. Sample 122-764B-25R-1, 97-99 cm. 2. Branching colony of Retiophyllia paraclathrata Roniewicz. Matrix is pelletal fossiliferous micrite. Polished section. Sample $122-764 \mathrm{~B}-23 \mathrm{R}-1,48-50 \mathrm{~cm}$. 3. Hand specimen showing colony of Astreomorpha crassisepta Reuss. Sample 122-764B-23R-1, 8-9 cm. 4. Hand specimen showing colony of Astreomorpha confusa Winkler. Sample 122-761C-16R-1, 32-34 cm. 